\title{
Quantitative organic-walled dinoflagellate cyst stratigraphy across the Eocene-Oligocene Transition in the Gulf of Mexico: A record of climate- and sea level change during the onset of Antarctic glaciation
}

\author{
Alexander J.P. Houben ${ }^{1,2 *}$, Willemijn Quaijtaal ${ }^{1,3}$, Bridget S. Wade ${ }^{4}$, \\ Stefan Schouten ${ }^{5}$ and Henk Brinkhuis ${ }^{1,5}$
}

With 8 figures, 2 plates and 1 table

\begin{abstract}
The Eocene - Oligocene Transition (EOT, 34-33.5 Ma) marks a major transition in Cenozoic climate evolution through the relatively rapid establishment of a continental-scale ice sheet on Antarctica. The EOT is characterized by two $200 \mathrm{kyr}$ spaced shifts (termed EOT-1 and Oi-1) in the oxygen isotopic composition $\left(\delta^{18} \mathrm{O}\right)$ of benthic foraminifera, representing both changes in continental ice-volume and temperature. Estimates of the timing and magnitude of these changes during this critical phase in Earth's climatic evolution are controversial. Here we present marine palynological assemblage data, in particular of organic-walled dinoflagellate cysts (dinocysts), across a classic upper Eocene to lower Oligocene neritic succession cored in Alabama, USA; the Saint Stephens Quarry (SSQ) borehole. These palynological data combined with lithological information allow the identification of three sequence boundaries across the EOT. Critically, we identify a sequence boundary at the level corresponding to the EOT-1. Integrated sea level and paleotemperature records show that EOT-1 primarily represents cooling with some minor and transient continental ice sheet expansion. Furthermore, we identify a significant hiatus, likely caused by major sea level fall at the base of Magnetochron $\mathrm{C} 13 \mathrm{n}$ that corresponds to the Oi-1 shift. This clarifies the $\delta^{18} \mathrm{O}$ records from SSQ that essentially lack the expected pronounced shift to positive $\delta^{18} \mathrm{O}$ values so characteristic for Oi-1. Furthermore, we document originations and extinctions of potentially temperature-sensitive dinocysts associated with the EOT-1. In contrast, the Oi-1 does not stand out as period of substantial dinoflagellate turnover. The combined results illustrate that major cooling, limited and transient ice growth and major biotic change were occurring before the full-size expansion of the Antarctic cryosphere.
\end{abstract}

Key words. Organic-walled dinoflagellate cysts, Eocene-Oligocene Transition, relative sea level, temperature, sequence stratigraphy, Gulf of Mexico

\footnotetext{
Authors' addresses:

${ }^{1}$ Marine Palynology and Paleoceanography, Department of Earth Sciences, Faculty of Geoscience, Utrecht University, P. O. Box 80115, 3508 TC Utrecht, The Netherlands. H.Brinkhuis@uu.nl

${ }^{2}$ Geological Survey of the Netherlands TNO, Princetonlaan 6, 3584CB, Utrecht, The Netherlands.

${ }^{3}$ Research Unit for Palaeontology, Department of Geology, Ghent University, Krijgslaan 281/S8, 9000 Gent, Belgium. willemijn.quaijtaal@ugent.be

${ }^{4}$ Department of Earth Sciences, University College London, Gower Street, London, WC1E 6BT, United Kingdom. B. Wade@ucl.ac.uk

${ }^{5}$ NIOZ Netherlands Institute for Sea Research, PO Box 59, 1790 AB Den Burg, The Netherlands. Schouten@nioz.nl

* Corresponding author: Alexander.Houben@tno.nl
} 


\section{Introduction}

The Eocene - Oligocene Transition (EOT, 34-33.5 Ma) marks the first continental-scale glaciation of Antarctica in the Cenozoic. Oxygen isotope ratios $\left(\delta^{18} \mathrm{O}\right)$ from marine benthic foraminifera record the EOT as a $\sim 200 \mathrm{kyr}$ spaced $\sim 1.5 \%$ o two-step positive shift that may represent both global cooling and increasing continental ice volume (Zachos et al. 1996, Coxall et al. 2005, Pearson et al. 2008, Scher et al. 2011). Recent studies have attributed the older of the two shifts (EOT-1) primarily to cooling and (transient) ice-volume accumulation (Lear et al. 2008, Houben et al. 2011, Bohaty et al. 2012, Wade et al. 2012), whereas the younger shift (the 'Oligocene isotope event 1', Oi-1 after Miller et al. 1991) is principally attributed to East Antarctic ice-sheet expansion (Lear et al. 2008, Pusz et al. 2011, Scher et al. 2011, Bohaty et al. 2012). One way of assessing cryosphere growth across the EOT is through acquiring information on glacio-eustatic sea level change in farfield (with respect to the locus of ice-accumulation) sedimentary sections (e.g., Houben et al. 2011). Although it is now becoming increasingly clear that glacio-eustatic sea level change may not be considered globally uniform (Milne and Mitrovica 2008, Raymo et al. 2011, Stocchi et al. 2013), sites far away from the locus of ice growth are not affected by ice-proximal gravitational processes and are therefore more likely to qualitatively approximate a theoretical eustatic sea level contribution.

A classic shelf section from the Gulf of Mexico (GoM) in Alabama, the Saint Stephens Quarry (SSQ) is a regional reference site for the Eocene-Oligocene boundary interval (Miller et al. 2008 and references therein, Fig. 1) and has been studied for decades in order to deconvolve changes in relative sea level, resulting in multiple, partly contradictive, sequence stratigraphic interpretations. The recovery of a core (Miller et al. 1993) allowed for more accurate integration of different proxy records in recent years, including stratigraphically and paleoclimatologically significant oxygen-isotope data (Katz et al. 2008, Miller et al. 2008, Wade et al. 2012). Previous sequence stratigraphic interpretations from the SSQ outcrop and core were primarily based on analysis of litho- and biofacies. However, in a largely ice-free greenhouse world, sea level fluctuations were theoretically of smaller magnitude than those driven by glacioeustasy and in turn, shelf morphologies were different in an ice-free world (e.g., Sømme et al. 2009). Essentially, smaller amplitude sea level variability in greenhouse climates would allow for across-shelf progradation of sedimentary strata, resulting in more laterally expanded shelves with a smaller water-depth-gradient across the shelf. Therefore, the reconstruction of changes in local water depth may not always be appropriate when it comes to identifying sea level variability. Furthermore, lithostratigraphic and biofacies analyses often encounter problems in terms of sequence stratigraphic interpretation when it comes to intervals with sedimentary condensation, that may be both associated with sequence boundaries and maximum flooding episodes. Therefore, approaches that yield information on coastal proximity also need to be considered when it comes to understanding past sea level variability.

Dinoflagellates are a group of predominantly marine surface-dwelling algae. Some dinoflagellates produce preservable organic-walled resting cysts as part of a complex life cycle. Because of the life-strategy of the organic cyst-forming dinoflagellates and the adaptation of dinoflagellate species to specific surface water conditions, fossil dinocyst assemblages can be interpreted to reconstruct proximal to distal trends in shelf environments (e. g., Brinkhuis 1994, Pross and Brinkhuis 2005, Sluijs et al. 2008). We here present highresolution palynological data that we consequently use to elucidate changes in relative sea level across the EOT in the GoM. We compare these trends with the previously published sea surface temperature reconstructions using the Tetraether indeX of 86 carbon atoms $\left(\mathrm{TEX}_{86}\right.$, Schouten et al. 2002) of Wade et al. (2012), which is here extended for the intervals preceding and postdating the EOT. Our new dinocyst dataset sheds new understanding of sea level change through this critical climate transition and allows us to tie SST change to the sequence stratigraphic record. Coupled with existing stable isotope, bio- and magneto-stratigraphy studies at this site (e. g., Miller et al. 2008, Katz et al. 2008, Wade et al. 2012), we present a new integrated record of relative sea level changes.

Apart from changes in relative sea level, the effects of climatic cooling (Zanazzi et al. 2007, Lear et al. 2008, Schouten et al. 2008, Wade et al. 2012), increased seasonality (Ivany et al. 2000, Eldrett et al. 2009) and modifications of the hydrological cycle (Kobashi et al. 2001) across the EOT are likely to have affected the biota along the continental shelves of the GoM. The presented dinocyst assemblage data may also provide insight about biotic turnover in shallow marine environments of the GoM during the late Eocene to early Oligocene transition into the icehouse. 


\section{Material and Methods}

\subsection{Geological setting and material}

Cenozoic sedimentation along the northern margin of the GoM is characterized by rapid sediment input and thick, progradating depositional sequences, which intertongue with deltaic shelf-edge sediments (Jaramillo and Oboh-Ikuenobe 1999 and references therein). Eocene-Oligocene units were deposited in the shallow marine setting of a passive margin. In general, the upper Eocene sediments are characterized by a fine-grained nature, whereas the lower Oligocene constitutes one of the great progradational wedges in the northern Gulf of Mexico (Jaramillo and ObohIkuenobe 1999 and references therein). We here follow Miller et al. (1993) in applying the lithostratigraphic units from the upper Eocene Jackson and lower Oligocene Vicksburg and Chickasawhay Groups for the Gulf Coast (see also Dockery 1982, Mancini and Tew 1991).

The upper Eocene Jackson Group includes (from lower to upper) the Moodys Branch Formation (Fm.) and the North Twistwood Creek Clay Fm. The Cocoa Sand, Pachuta Marl and the Shubuta Clay constitute the Yazoo Clay Fm. The lower Oligocene Vicksburg Group includes the laterally gradational Forest Hill Sand, Red Bluff Clay, Bumpnose Fm., the informal Mint Spring fm. and the Marianna Limestone. The
Glendon Limestone and Bucatunna Clay constitute the Byram Fm. (Miller et al. 1993 and references therein).

The SSQ borehole was continuously cored by ARCO Oil and Gas Company in 1987 near the highest point on the southwest rim of the Saint Stephen's Quarry ( $31^{\circ} 33^{\prime}$ N, $88^{\circ} 02^{\prime}$ W; Fig. 1). Coring began in the outcropping Oligocene Chickasawhay Fm. and extended for $76.2 \mathrm{~m}$ into the upper Eocene Moodys Branch Fm. The paleowaterdepth for the SSQ corehole was reported to be $50-100 \mathrm{~m}$ based on biofacies analysis (Miller et al. 2008).

We employ and subsequently refine the sequences and their abbreviations used by Miller et al. (2008, Fig. 2). These sequences are composed of: (I) The Moodys Branch Fm. and North Twistwood Creek Clay (MNT-sequence), (II) the Cocoa Sand and Pachuta Marl (CP-sequence), (III) the Bumpnose Fm. and Red Bluff Clay (BRB-sequence), (IV) Marianna Limestone and Glendon Limestone (MMG-sequence), (V) Byram Fm. and/or Bucatunna Clay (BB-sequence) and (VI) the Chickasawhay Fm. (C-sequence).

\subsection{Previous sequence stratigraphic studies from the EOT in the GoM}

The upper Eocene to lower Oligocene sequences in southern Alabama have been the subject of many magnetostratigraphic, sedimentological, biostratigraphic and sequence stratigraphic studies (Hazel et

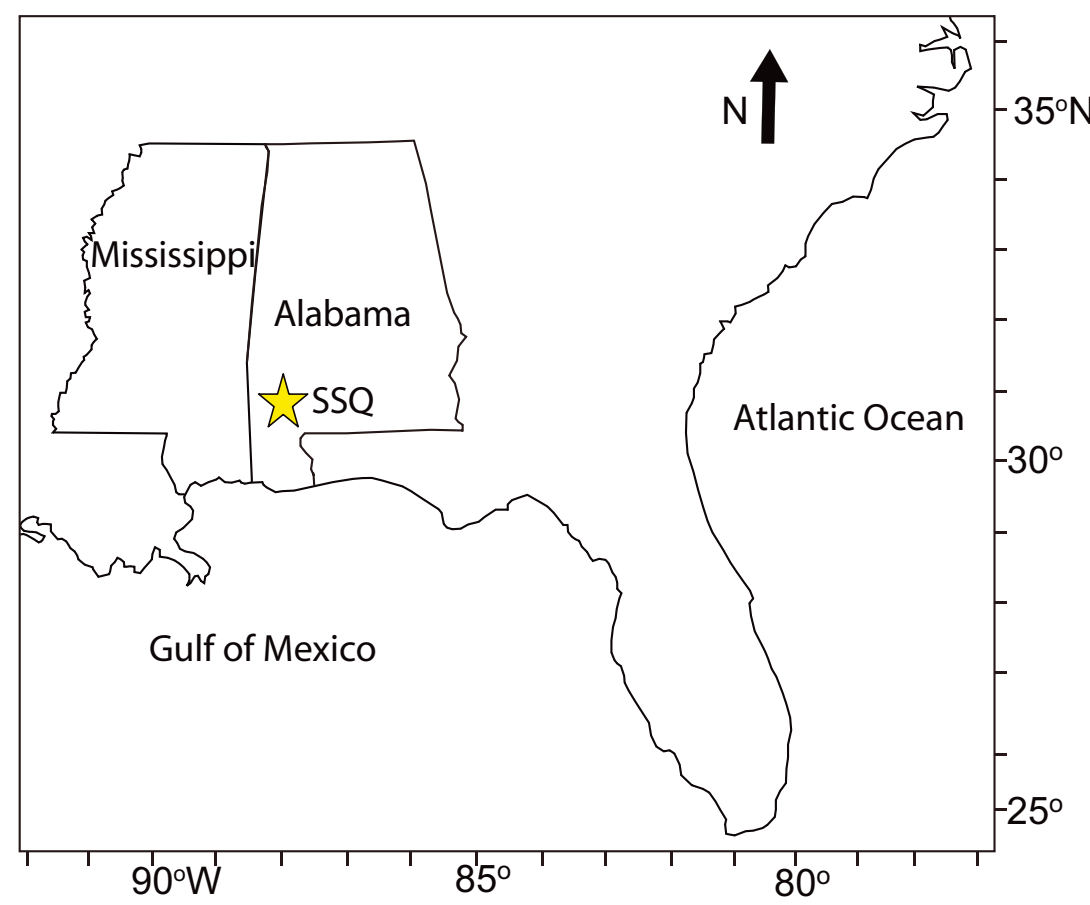

Fig. 1. Location of the Saint Stephens Quarry borehole in Alabama, USA. 
Chronostrat. Lithostratigraphy (Miller et al., 2008) Lithology

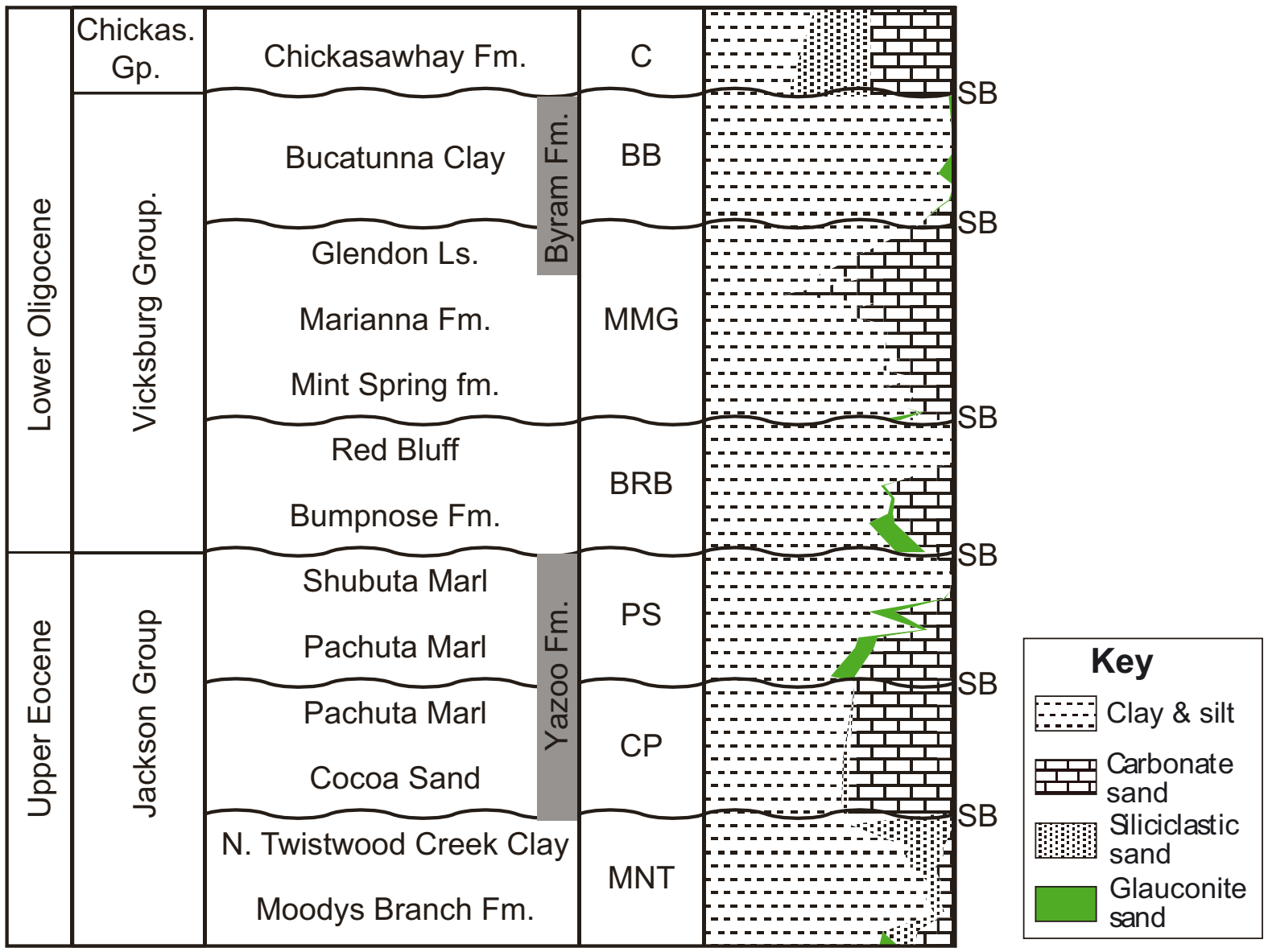

Fig. 2. Comparison of the lithostratigraphic nomenclature of the upper Eocene and Oligocene succession in Alabama and the sequence stratigraphic interpretation of Miller et al. (2008). Figure is adapted after the latter.

al. 1980, Siesser et al. 1985, Miller et al. 1993, Tew and Mancini 1995, Mancini 2000, Jaramillo and ObohIkuenobe 1999, Miller et al. 2008). The SSQ succession has been the most studied but in terms of its sequence stratigraphic interpretation remains controversial. Importantly, there is disagreement on one critical interpretation from both the SSQ core and the outcrop sections, i. e. whether there is indication of a major Lowest Oligocene sequence boundary and corresponding sea level fall in the SSQ-record. This is significant because of its likely relationship with the global Oi-1 positive $\delta^{18} \mathrm{O}$ excursion. At this stage, one interpretation maintains that the lowermost Oligocene contact between the Shubuta Marl and the Bumpnose Fm. (PS to BRB sequence sensu Miller et al. 2008) is associated with a third order maximum flooding surface (MFS) within a sequence (Loutit et al. 1988,
Baum and Vail 1988, Jaramillo and Oboh-Ikuenobe 1999). In contrast, other interpretations maintain that there is a sequence boundary at this level, corresponding to sea level fall (Dockery 1982, Miller et al. 1993).

Based on lithologic-, biofacies-, biostratigraphic-, gamma log, and benthic foraminiferal isotope data, Miller et al. (2008) suggest that the contact between the Pachuta-Shubuta (PS) and BRB sequences corresponds to a third order sequence boundary, suggesting major sea level fall in association with the Oi-1. However, no substantial hiatus was inferred. Furthermore, the sequence boundary was identified between two points of reversed magnetic polarity (Miller et al. 1993), whereas the Oi-1 shift is tied to the lowermost portion of the normal magnetic polarity Chron $\mathrm{C} 13 \mathrm{n}$ (Zachos et al. 1996, Coxall and Wilson 2011). This means that if the Oi-1 shift reflects expanding ice 
sheets, its glacioeustatic fingerprint should be sought at the base of Chron $\mathrm{C} 13 \mathrm{n}$, in the lower part of the Bumpnose Limestone. Miller et al. (2008) furthermore reported three previously undetected possible sequence boundaries and postulated that none of these corresponds to the EOT-1 shift. In a later publication by Miller et al. (2009), a tentative sequence boundary was placed within the PS sequence, primarily on the basis of an overlying glauconite bed, interpreted to represent transgressive conditions. This level approximates the EOT-1 shift and may hence indeed correspond to a previously undetected hiatus or unconformity after all.

\subsection{Methods}

\subsubsection{Palynological processing and analyses}

In total 57 samples were processed using palynological preparation techniques. Carbonates and silicates were removed by treatment with $30 \% \mathrm{HCl}$ and $38 \% \mathrm{HF}$ respectively. After each acid step, samples were washed by decanting with water and settling for 24 hours. Samples were sieved over a $15 \mu \mathrm{m}$ mesh-sieve. To break up agglutinated particles in the residue, the samples were placed in an ultrasonic bath for 5 minutes. The remaining residue was transferred to glass tubes, subsequently centrifuged (2000 rpm) and excess water was removed. For slide preparation, samples were transferred to vials and glycerin water was added. The residue was then homogenized and a droplet of each residue was mounted on a slide. Glycerin jelly was added and the mixture was stirred and sealed with nail varnish. All slides are stored in the collection of the Laboratory of Palaeobotany and Palynology, Utrecht University. Taxonomy, unless otherwise indicated follows that cited in Fensome et al. (2008). Several stratigraphically and paleo-environmentally significant taxa are illustrated in Plate 1 and Plate 2.

\subsubsection{Dinoflagellate cyst paleoecology and grouping of taxa}

About $20 \%$ of living dinoflagellate species produce organic walled dinocysts that may preserve in sediments (Fensome et al. 1993). Some Recent dinocysts have been traced back to the motile dinoflagellate stage through incubation experiments (Rochon et al. 2009, Mertens et al. 2009, Ribeiro et al. 2010). It is becoming increasingly clear from such studies that modern dinoflagellate species may produce highly variable cyst morphologies, likely depending on the physiochemical characteristics of the water mass (Lewis et al. 2001).

Dinocyst taxonomy is typically based on relatively subtle morphological details, which seen in the light of these incubation experiments is problematic if one wants to determine a 'real' dinocyst species' biological, ecological or statistical relevance. Therefore, in order to extract meaningful paleoecological information from dinocysts, it is important to establish whether the recorded dinocyst specimens represent relatively consistent entities or not (cf. Sluijs and Brinkhuis 2009). To obtain a first-order assessment of potential ecological relationships between environmental parameters and dinocyst taxa, we here consider groupings of dinocyst taxa that are morphologically closely related, rather than 'average' single species concepts. These taxa may either be strictly or loosely defined species, groups of species within genera, genera themselves or even groups of genera.

Specifically, information regarding relative sea level change may be obtained by assigning dinocysts to such (eco)morphological groups. The premise of dinocysts as indicators of changes in relative sea level is founded on the observation that different morphological groups are dominant in specific environments along a proximal to distal shelf transect (e.g., Brinkhuis 1994, Pross and Schmiedl 2002, Röhl et al. 2004, Pross and Brinkhuis 2005, Torricelli et al. 2006, Sluijs et al. 2008). For instance, open oceanic assemblages are typically dominated by Impagidinium spp. and Nematosphaeropsis spp. The Spiniferites complex (cpx) of forms on the other hand is a generalistic cosmopolitan group and typically reaches high abundance in outer neritic and upper bathyal environments. Hence, high relative abundance of these groups is considered indicative of relatively offshore settings on a passive margin. Since their maximum abundances theoretically correspond to ultimately distal environments, these can as such be interpreted to represent 'maximum flooding surfaces' (MFSs) in third order sequence stratigraphic nomenclature (Miller et al. 2005). Taxa of the Areoligera cpx are often found in neritic settings, when environments are highly energetic and influenced by wave and current action (Brinkhuis 1994, Sluijs et al. 2009). We therefore interpret high abundance of Areoligera cpx from ancient neritic settings to reflect third order transgressive systems tracts (TSTs) in sequence stratigraphic terms, and thus accompanying shifts from proximal to more distal environments 

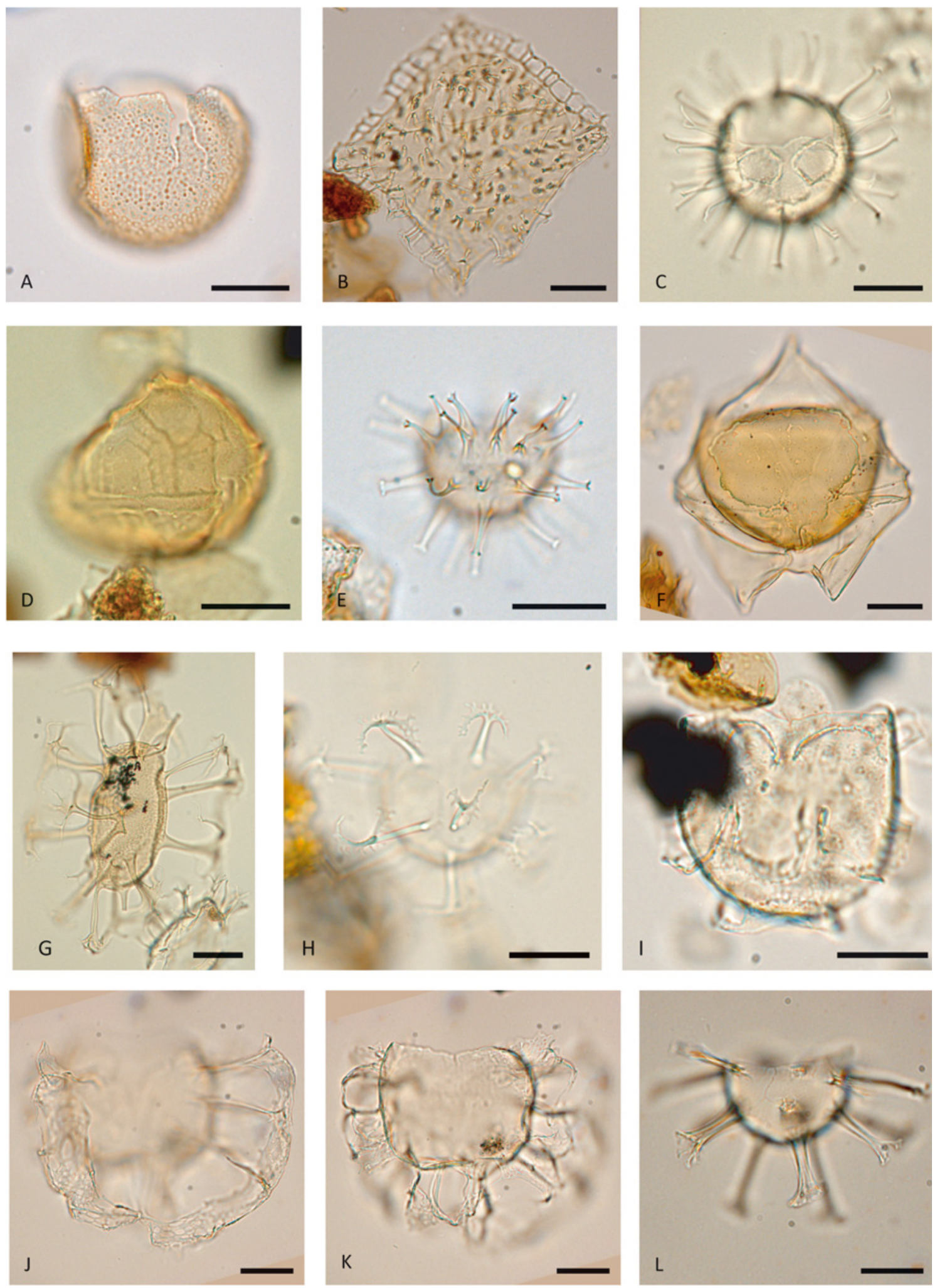

Plate 1. Transmissive light photomicrographs of selected dinocyst taxa. The scale bar represents $10 \mu \mathrm{m}$. A: Batiacasphaera compta, B: Charlesdowniea clathrata, C: Cleistosphaeridium ancyrea, D: Cribroperidinium giusseppei, E: Dapsilidinium spp., F: Deflandrea heterophlycta, G: Distatodinium ellipticum, H: Enneadocysta pectiniformis, I: Hemiplaciphora semilunifera, J: Glaphyrocysta semitecta (ventral view), K: Glaphyrocysta semitecta (dorsal view), L: Homotryblium floripes. 

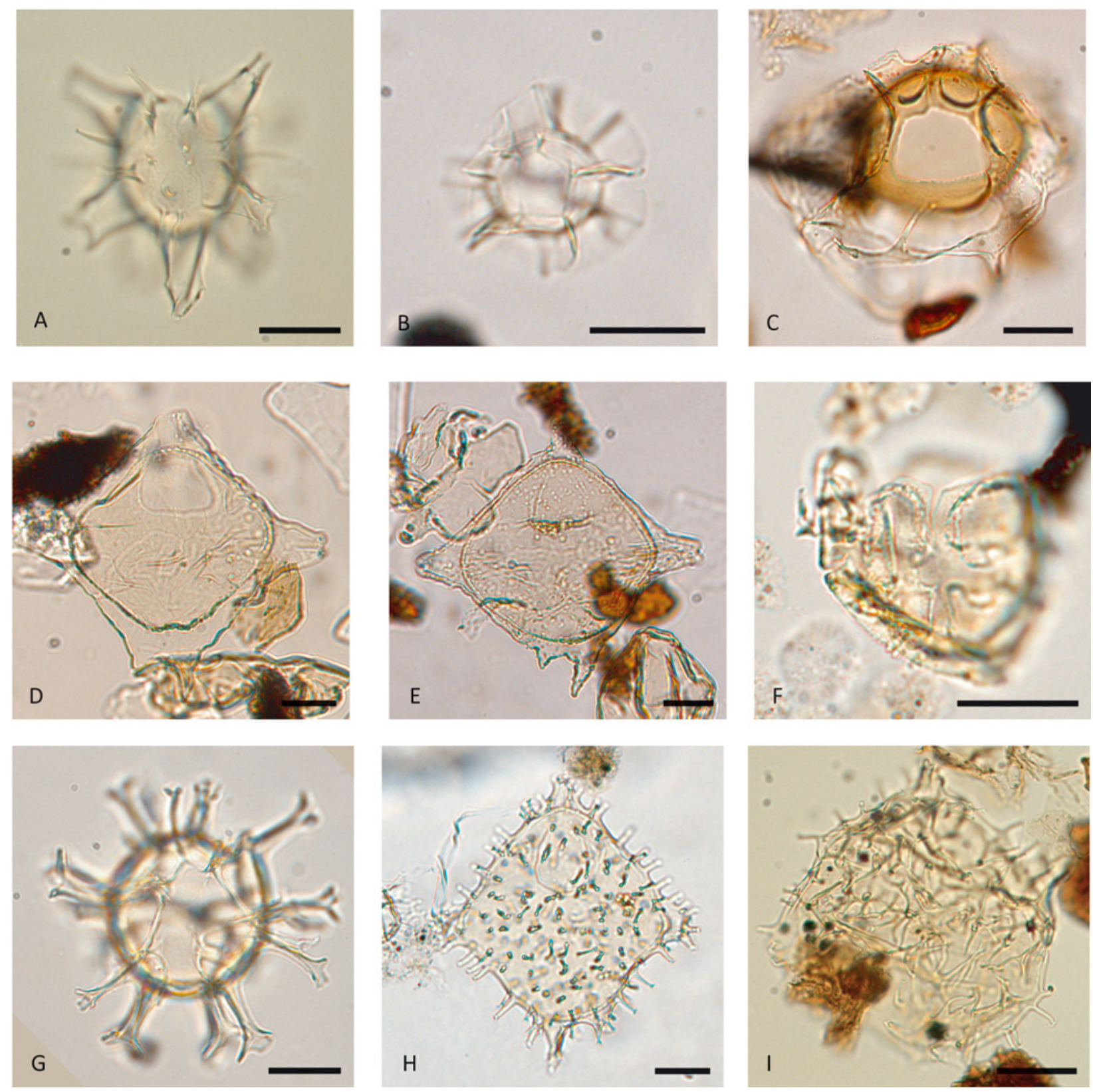

Plate 2. Transmissive light photomicrographs of selected dinocyst taxa. The scale bar represents $10 \mu \mathrm{m}$. A: Hystrichokolpoma rigaudiae, B: Impagidinium velorum, C: Pentadinium alabamaensis, D: Rhombodinium draco, E: Rhombodinium cf. draco, F: Schematophora speciosa, G: Spiniferites spp., H: Wetzeliella articulata, I: Wetzeliella gochtii.

(Brinkhuis 1994, Crouch and Brinkhuis 2005, Sluijs et al. 2008). Representatives of the Goniodomid family (grouped here under the Homotryblium cpx) are typically found in association with relatively inshore, restricted and lagoonal conditions, settings of variable salinity. We therefore interpreted high loadings of these taxa to be indicative of very inshore conditions, developing typically during regressive high stand systems tracts (HSTs). Since these can also be transported to more distal environments during regressive phases, they are in both cases indicative of regressive trends.

Summarizing, an idealized sequence stratigraphic succession from maximum flooding, regression, development of the HST, transgression, development of the TSTs and again maximum flooding is typically 
characterized by an assemblage succession from $\mathrm{Spi}$ niferites cpx to Homotryblium cpx to Areoligera cpx and Spiniferites cpx respectively. As such, sequence boundaries are characterized by sharp transitions from relatively inshore conditions (high abundance of Homotryblium cpx) to transgressive (Areoligera cpx) facies and/or more offshore conditions (Spiniferites cpx).

Furthermore, morphologically fundamentally distinct dinocysts of the peridinioid Family are likely related to heterotrophic dinoflagellates rather than the autotrophic taxa mentioned above, and are as such more abundant in nutrient rich environments (see discussion in Sluijs et al. 2005, Sluijs and Brinkhuis 2009). Many of these peridinioid taxa are typically also tolerant to lower salinity and may therefore be also more abundant in relatively inshore environments, although they may also inhabit nutrient rich oceanic environments (Sluijs et al. 2005). Table 1 shows the composition of (eco)morphological complexes employed for this study. This only includes groups that yield a substantial relative abundance. For that reason the Impagidinium and Nematosphaeropsis complexes are not used.

In Recent dinocyst assemblages, taxonomic diversity strongly depends on the degree of ecological stress (e. g., Patten 1962, Bradford and Wall 1984). Since the degree of ecological disturbance in neritic settings is often related to relative shoreline proximity, the dinocyst diversity signal may thus also be broadly used as an indicator of the latter. This approach has also been taken in several Paleogene dinocyst studies. In particular, a study on early Oligocene assemblages from an epicontinental basin in Central Europe revealed a relation between dinocyst diversity values and increasing distance from the shoreline (Pross and Schmiedl 2002). Maximum values of the Shannon-Wiener information index $(\mathrm{H}(\mathrm{S}))$, which was used to characterize the diversity of dinocyst assemblages, occurred in the center of the basin at a distance of $\sim 15 \mathrm{~km}$ from the paleo-shoreline. Assemblages from more proximal settings exhibited consistently lower $\mathrm{H}(\mathrm{S})$ values. Hence, the diversity of dinocyst assemblages can render information on stress, and hence onshore offshore trends (Sluijs et al. 2005). The ShannonWiener information index $\mathrm{H}(\mathrm{S})$ is here used to characterize the diversity of assemblages. We calculated this diversity index using taxonomic differentiation to the generic level.

Furthermore, we performed Principal Component Analysis (PCA) on the grouped dinocyst assemblage dataset using the $\mathrm{C} 2$-software package. PCA evaluates how the variation in the assemblage data is explained by the empirically established paleo-ecological entities and thus how these intrinsically relate.

\subsubsection{Paleotemperature data}

Sea surface temperatures (SSTs) at SSQ were previously reported by Wade et al. (2012), and obtained by

Table 1. Overview and composition of dinocyst complexes and groups.

\begin{tabular}{|c|c|c|}
\hline Complex & Included genera & Environmental significance \\
\hline Areoligera $\mathrm{cpx}$ & $\begin{array}{l}\text { Areoligera, Glaphyrocysta, Hemiplaciphora, } \\
\text { Membranophoridium, Schematophora }\end{array}$ & $\begin{array}{l}\text { Inner neritic, adapted to dynamic sur- } \\
\text { face-water conditions, indicative of } \\
\text { transgressions }\end{array}$ \\
\hline Cleistosphaeridium cpх & $\begin{array}{l}\text { Batiacasphaera, Cleistosphaeridium, Dapsili- } \\
\text { dinium, Diphyes, Enneadocysta, Histiocysta, } \\
\text { Hystrichokolpoma }\end{array}$ & Inner to outer neritic \\
\hline Cordosphaeridium cpx & $\begin{array}{l}\text { Achilleodinium, Cordosphaeridium, Opercu- } \\
\text { lodinium, Samlandia, Thalassiphora }\end{array}$ & Inner to outer neritic \\
\hline Deflandrea - Wetzeliella cpx & $\begin{array}{l}\text { Charlesdowniea, Deflandrea, Rhombodinium, } \\
\text { Wetzeliella, Wilsonidium }\end{array}$ & $\begin{array}{l}\text { Possibly heterotrophic life style. } \\
\text { Eutrophic conditions }\end{array}$ \\
\hline Homotryblium cpx & $\begin{array}{l}\text { Eocladopyxis, Heteraulacacysta, Homotry- } \\
\text { blium, Polysphaeridium }\end{array}$ & Inner neritic to lagoonal \\
\hline Spiniferites cpx & $\begin{array}{l}\text { Achomosphaera, Hystrichostrostrogylon, } \\
\text { Rottnestia and Spiniferites with the exception } \\
\text { of } S . \text { pseudofurcatus }\end{array}$ & Outer neritic to oceanic \\
\hline Protoperidinioideae & Lejeunecysta and Selenopemphix & $\begin{array}{l}\text { Heterotrophic life style. Eutrophic } \\
\text { conditions }\end{array}$ \\
\hline
\end{tabular}


using $\mathrm{Mg} / \mathrm{Ca}$ ratios derived from the planktonic foraminifera and the distribution of archaeal membrane lipids $\left(\right.$ TEX $\left._{86}\right)$. Evans et al. (2016) conducted laserablation trace element analysis on planktonic foraminifera at SSQ which showed excellent agreement with the previous solution $\mathrm{Mg} / \mathrm{Ca}$ data. Wade et al. (2012) only reported data for the EOT interval (34.5-33 Ma) and not for the remainder of the late Eocene (36.7-34 $\mathrm{Ma})$ and early Oligocene $(<\sim 33 \mathrm{Ma})$ part of the succession. We therefore extended the $\mathrm{TEX}_{86}$ data here and present a $\mathrm{TEX}_{86}$ record from 32 to $36.5 \mathrm{Ma}$. The method for $\mathrm{TEX}_{86}$ analysis follows those outlined in Wade et al. (2012). The Branched Isoprenoid Tetraether-index (BIT, Hopmans et al. 2004), a proxy that reflects the relative contribution of soil-derived bacterial lipids over marine derived archaeal lipids, was also calculated. The BIT-index can be interpreted to reflect trends in the relative contribution of soil over marine-derived organic matter.

\section{Results}

\subsection{Trends in palynomorph categories}

There are major abundance variations in the different major palynomorph categories (Fig. 3). Dinocysts and terrestrial palynomorphs, the latter mostly in the form of angiosperm pollen grains, dominate the palynological associations. Acritarchs are however also abundant and a conspicuous abundance peak of the freshwater/brackish algae Cyclopsiella spp. (Santarelli et al.

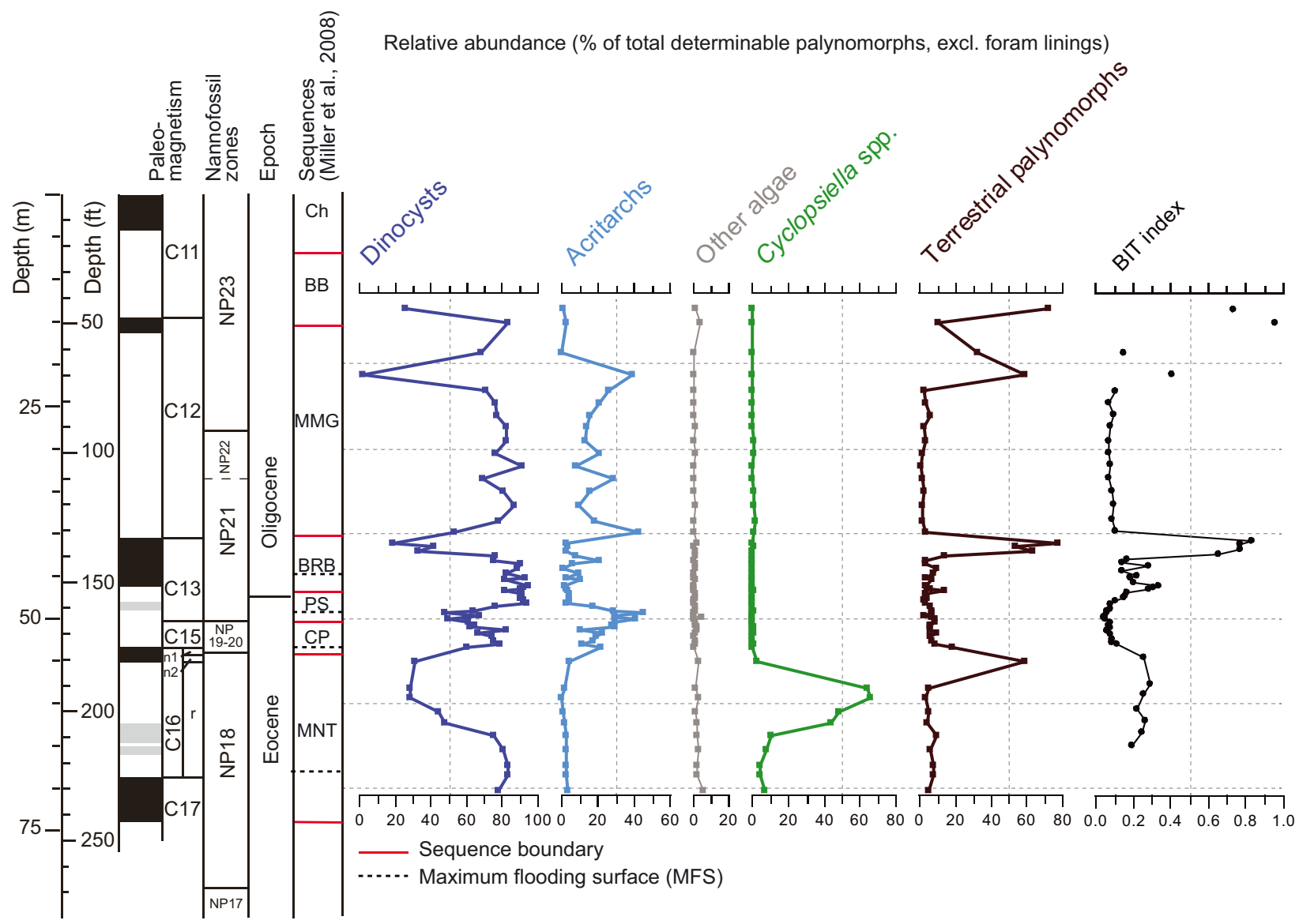

Fig. 3. Relative abundance (\%) of the main palynomorphs categories; dinocysts, acritarchs, other (green) algae, Cyclospiella spp. and terrestrial palynomorphs. The biomagnetostratigraphic framework, sequences and initial sequence stratigraphic interpretation at the left are modified after Miller et al. (2008). MNT = Moodys Branch Fm. - North Twistwood Clay Sequence, $\mathrm{CP}=$ Cocoa Sand - Pachuta Marl Sequence, PS = Pachuta Marl - Shubuta Marl Sequence, BRB = Bumpnose Formation - Red Bluff Sequence, $M M G=$ Mint Spring Formation - Marianna Formation - Glendon Limestone Sequence, BB $=$ Byram Formation - Bucatunna Formation Sequence, $\mathrm{C}=$ Chickasawhay Formation Sequence. Note that the position of the E/O-boundary is inferred on the basis of the Highest Occurrence of larger Pseudohastigerina micra planktonic foraminifera (Wade et al. 2011). 
1998, Jaramillo and Oboh-Ikuenobe 1999) is recorded between 62.5 and $58 \mathrm{~m}$ depth.

High loadings of dinocysts and acritarchs are typically interpreted to represent marine conditions whereas increased abundance of terrestrial palynomorphs indicates riverine influence. Conspicuously, these major changes between marine and terrestrial palynomorph contributions are not recorded across the EOT-interval (52 and $43 \mathrm{~m}$ core depth), where essentially only marine palynomorphs are encountered. This implies that the expanded HSTs and Low Stand Systems Tracts (LSTs) of the Cocoa Sand-Pachuta (CP) and Pachuta-Shubuta (PS) sequences are not preserved. However, the upper Eocene Moodies Branch - North Twistwood (MNT-sequence), the lower Oligocene Bumpnose - Red Bluff Clay (BRBsequence) and the Mint Spring fm. - Marianna Fm. - Glendon Limestone (MMG-sequence) and the Byram Formation - Bucatunna Clay (BB-sequence) are characterized with well-developed HSTs, inferred from increased abundance of terrestrial palynomorphs and elevated BIT-values. This means that these sequence boundaries were not associated with major erosive features erosionally truncating the HSTs.

\subsection{Organic walled dinoflagellate cysts}

In the SSQ core succession we recorded 122 dinocyst taxa. These were grouped according to the species or generic level (see Supplementary Online Information for a quantitative distribution data). Some taxa were subsequently grouped under complexes for paleoenvironmental interpretation. Among the most abundant taxa are relatively long-ranging gonyaulacoid taxa such as Spiniferites ramosus, Cleistosphaeridium spp. and Homotryblium floripes. Some other taxa occur in dominant to rare presence in particular intervals; these are discussed separately in section 3.2.2.

In order to evaluate whether the empirical established environmental groupings as discussed in section 2.2.2 are indeed distinct environmental entities, we performed PCA on the relative abundance of the dinocysts (Fig. 4). The PCA clearly separates the environmentally relevant Spiniferites cpx, Homotryblium cpx, Deflandrea-Wetzeliella cpx along axis 1 (explaining $44 \%$ of the variance in the dataset) and axis 2 ( $33 \%$ of variance). This lends support to our empirically established paleo-environmental grouping strategy.

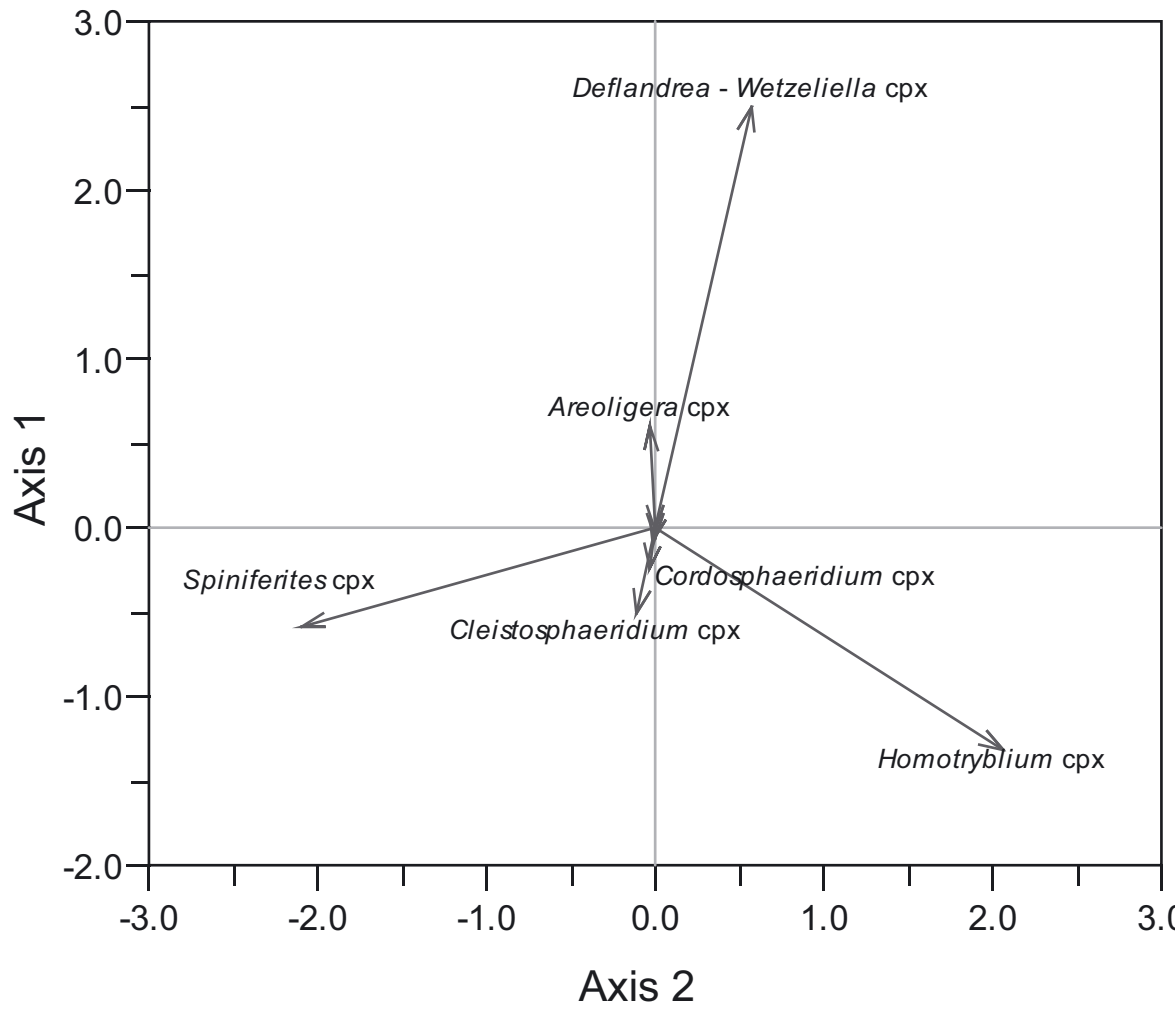

Fig. 4. Principal Component scatter plot of the relative abundance data from SSQ. The first two axes collectively explain $77 \%$ of the total variance in the dataset. Environmentally significant complexes plot oppositely within the PCA-plot, confirming their value as paleoecological entities. 


\subsubsection{Integrated indications for trends in coastal proximity}

Changes in dinocyst assemblages (Fig. 5) generally occur at critical intervals of the SSQ corehole sequence stratigraphy as presented by Miller et al. (2008). Based on these assemblages we suggest modifications of the sequence stratigraphy for the EOT interval between 52 and $40 \mathrm{~m}$ core depth (Fig. 6).

According to Miller et al. (2008) the lowermost part of the SSQ succession between 75-55 m core depth represents one sequence (MNT-sequence). The palynological associations are in agreement with this interpretation as they denote an expanded HST on the basis of the up-section increase abundance of terrestrial palynomorphs and fresh water/brackish algae Cyclopsiella. In the dinocyst assemblages we record increasing abundance of the proximal marine peridinioid dinocyst group Deflandrea-Wetzeliella cpx. The BIT index for the input of terrestrial organic matter is relatively high (0.2-0.4). A MFS is tentatively identified within this sequence at $68 \mathrm{~m}$ core depth on the basis of maximum abundance of marine palynomorphs. Apart from relatively high dinocyst diversity (Fig. 5), we do not record a distinct shift in the dinocyst assemblages. Near the sequence boundary at the top of the MNT-sequence (just below $54 \mathrm{~m}$ core depth) we record an abrupt shift to dominance of marine palynomorphs. Dinocyst assemblages become dominated by Spiniferites cpx, marking an abrupt shift to distal open marine conditions. BIT values drop $(<0.1)$ across the MNT-sequence boundary.

Above the MNT sequence boundary, dinocysts become more abundant (mainly outer neritic taxa like Cleistosphaeridium cpx, Spiniferites cpx). These taxa reach maximum abundances close to the reported maximum flooding surface (MFS) within the Cocoa Sand - Pachuta Marl sequence ( $\sim 53 \mathrm{~m}$ core depth, CP sequence, Miller et al. 2008, see Fig. 5). Above this MFS, dinocyst assemblages comprise marginal marine taxa like Wetzeliella-Deflandrea cpx and Homotryblium cpx. These decline in abundance across the sequence boundary overlying the $\mathrm{CP}$-sequence (50.3 m core depth).

Above the CP-PS sequence boundary (Fig. 6), Cleistosphaeridium cpx and Spiniferites cpx increase in abundance. Although typical transgressive taxa like Areoligera cpx are not encountered in abundance, glauconite is present above the sequence boundary suggesting this represents the TST of the PS-sequence. Spiniferites cpx reaches highest abundance at $49.6 \mathrm{~m}$ core depth, tentatively denoting a MFS in the PSsequence.

At $49.1 \mathrm{~m}$ core depth, the marginal marine/lagoonal group Homotryblium cpx becomes dominant, marking the ultimate HST of the PS-sequence (Fig. 6). Homotryblium cpx is replaced by Areoligera cpx and Spiniferites cpx, which collectively argues for transgressive conditions. This implies positioning of a sequence boundary at $49.1 \mathrm{~m}$. At this level, however, Miller et al. (2008) positioned a MFS in the PS-sequence, based on presumed evidence for sedimentary starvation. In a later publication, Miller et al. (2009) refined this statement by noting the up-section increase in glauconite, typically associated with highly energetic transgressive sequences and therefore interpreted the horizon as a sequence boundary, in support of the dinocyst-based inferences herein. The relative sea level fall leading to this sequence boundary is correlative to the EOT-1 shift recognized in the foraminiferal $\delta^{18} \mathrm{O}$ records (Wade et al. 2012). Within the PSsequence we record a MFS based on the maximal abundance of Spiniferites cpx $(47.8 \mathrm{~m}$ core depth, Fig. 6). Remarkably, this level closely corresponds to the most negative $\delta^{18} \mathrm{O}$ values of the 'EOT plateau'.

Miller et al. (2008) noted a sharp shift in biofacies across the Shubuta-Bumpnose contact, essentially from the shallow water Hanzawaia biofacies to the deeper water Siphonina-Uvigerina biofacies. This led Miller et al. (2008) to follow Miller et al. (1993) in placing a sequence boundary at the Shubuta-Bumpnose contact (46.9 $\mathrm{m}$ core depth). In contrast, others (Baum and Vail 1988, Loutit et al. 1988, Pasley and Hazel 1990, Mancini and Tew 1991, Jaramillo and Oboh-Ikuenobe 1999) have interpreted the Cocoa Sand through the Red Bluff Formation as a single sequence with the Shubuta Marl and Bumpnose Formation being separated by an MFS. These authors then interpreted the surface separating the two formations as a starvation surface caused by sediments being trapped onshore. Miller et al. (2008) showed that: (1) a benthic foraminiferal biofacies shift occurs abruptly across the $46.9 \mathrm{~m}$ contact; (2) the contact is in fact an erosional surface; and (3) the amount of glauconite increases $60 \mathrm{~cm}$ above the contact. The combination of an abrupt biofacies shift, and increase in glauconite is typical of sequence boundaries and is now supported by dinocyst assemblage data that describe a trend towards more proximal conditions through the top of the Shubuta and then progressively more offshore conditions (increasing Spiniferites cpx) in the lowermost part of the Bumpnose Formation. 


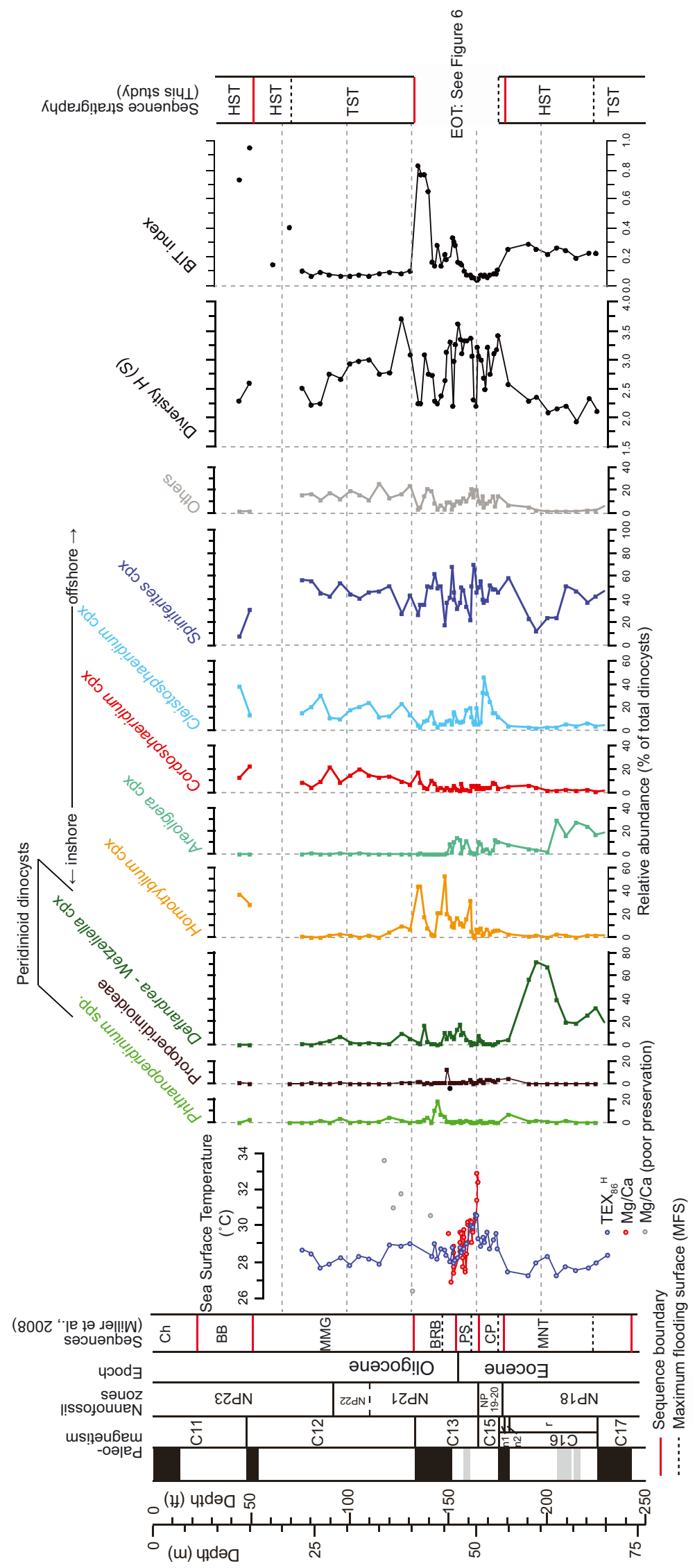

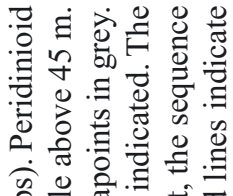

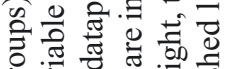

bo

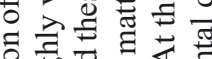

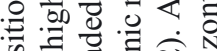

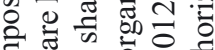

घ

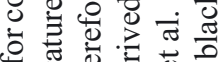

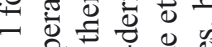

बै है

过范

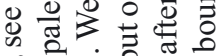

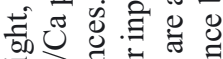

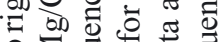

궁

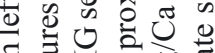

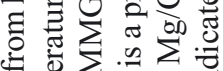

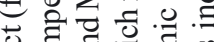

可 击

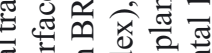

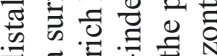

I

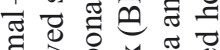

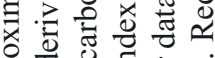

ठ워

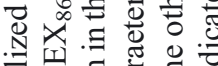

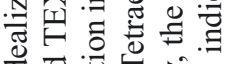

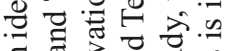

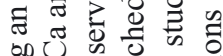

क्ष

元的苛

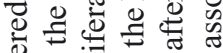

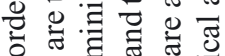

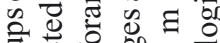

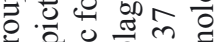

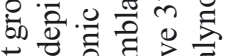

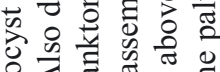

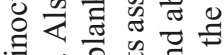

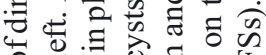

응

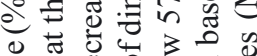

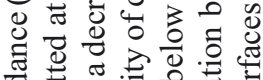

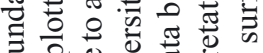

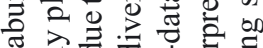

o 0

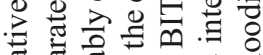

웡 \&

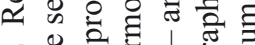

ம่

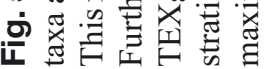




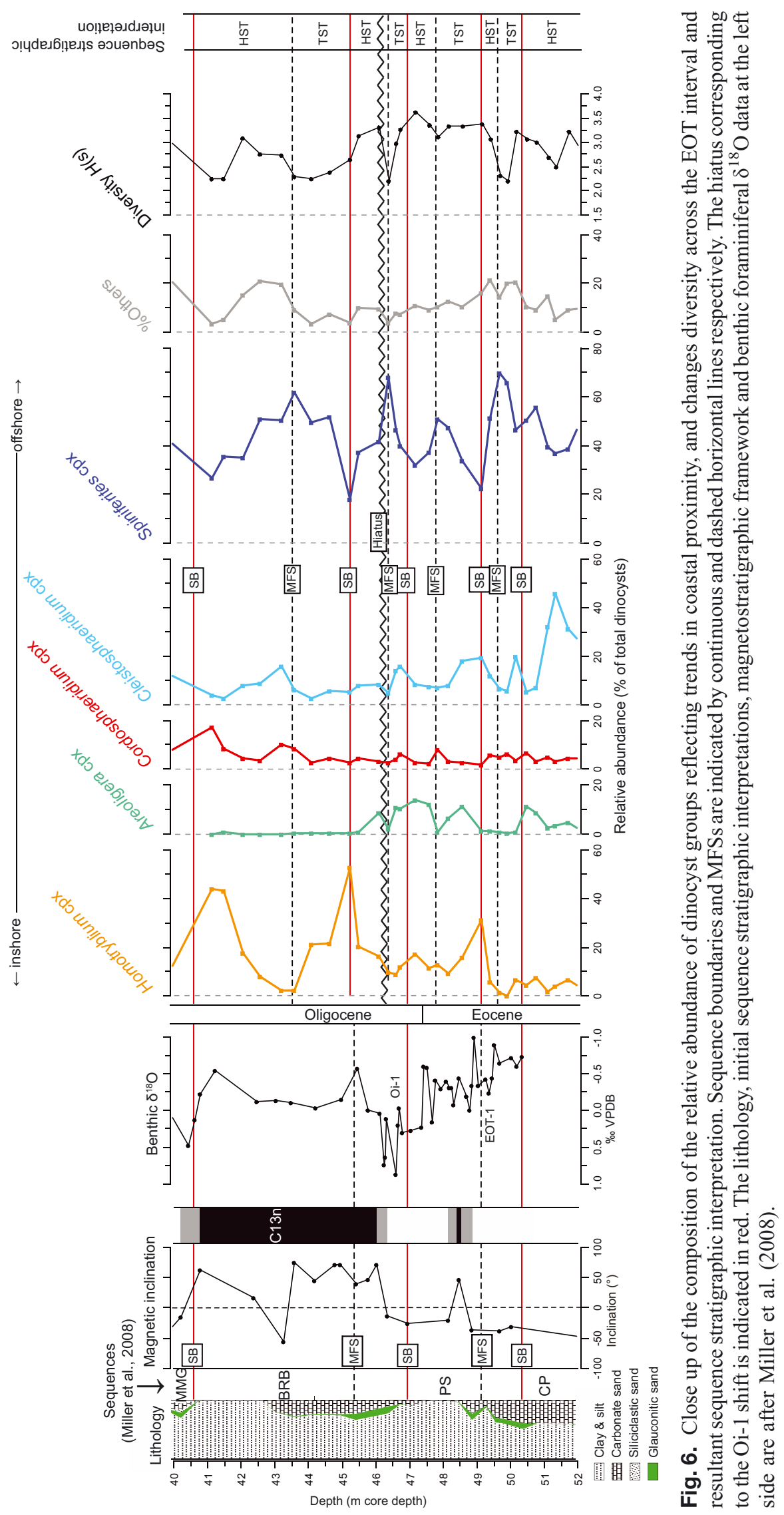




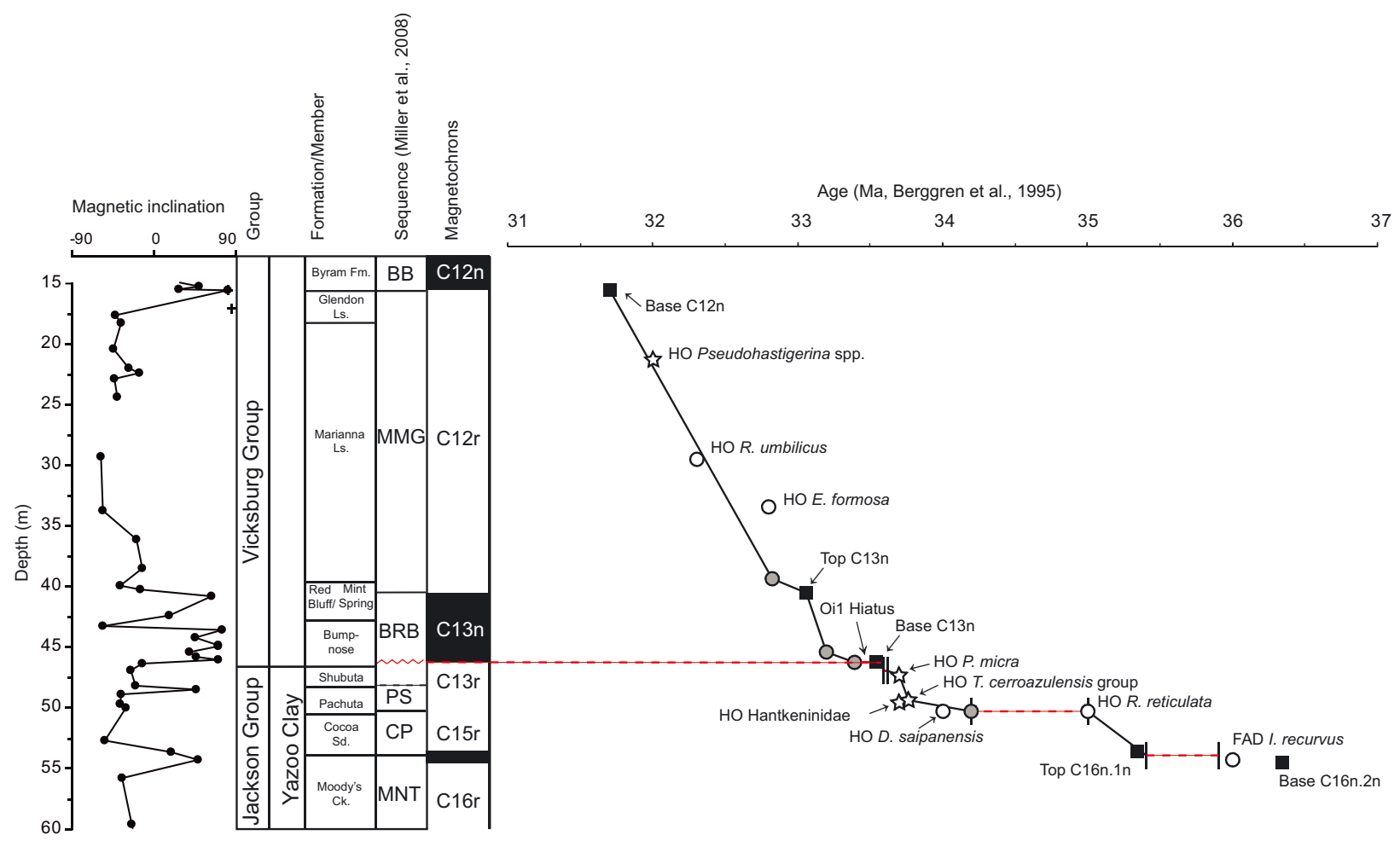

Fig. 7. Age-depth plot modified after Wade et al. (2012) with magnetic inclination data and interpretation. Black squares indicate paleomagnetic tie-points, stars indicate planktonic foraminifer events, white circles indicate calcareous nannofossil events and gray circles indicate carbon isotopic correlations. Vertical lines indicate the position of hiatuses.

Thus, we follow Miller et al. (2008) to interpret the Shubuta-Bumpnose contact as a sequence bounding unconformity and not an MFS. Miller et al. (2008) then postulated that this PS-BRB sequence boundary was directly associated with the Oi- $1 \delta^{18} \mathrm{O}$ shift. However, the sequence boundary is at a level corresponding to reversed polarity within Chron $\mathrm{C} 13 \mathrm{r}$ (Fig. 6) whereas the Oi- 1 globally corresponds to the base of $\mathrm{C} 13 \mathrm{n}$ and thus to normal polarity (Zachos et al. 1996). We here propose that this sequence boundary is not directly associated with the Oi-1 shift and in contrary may correspond to the transient so-called EOT-2 shift that slightly ( $<50 \mathrm{kyr}$ ) predates the Oi-1 (Katz et al. 2008, Miller et al. 2009).

Remarkably, we record high abundances of the distal dinocyst endmember, Spiniferites cpx in the uppermost sample assigned to reversed polarity (46.37 m core depth). Across the Chron C13 r-C13 n boundary ( $46.1 \mathrm{~m}$ core depth), the abundance of Spiniferites cpx drops substantially to be abruptly replaced by Homotryblium cpx and peridinioid dinocysts, indicating a shift to marginal marine conditions. This assemblage transition thus suggests that a previously undetected erosive hiatus is positioned at the level corresponding to the Chron $\mathrm{C} 13 \mathrm{r}-\mathrm{C} 13 \mathrm{n}$ boundary. This in turn implies that the interval reflecting the Oi-1 shift itself is not preserved at SSQ. This is supported by the absence of dinocyst taxa that are typically encountered in strata correlated to the Oi-1 shift in the Mediterranean and in the North Atlantic such as Areosphaeridium diktyoplokum (Brinkhuis and Biffi 1993, Brinkhuis 1994, Eldrett et al. 2004, Houben et al. 2011). Noteworthy, a biofacies change at this level is also suggested by the degree of planktonic foraminiferal preservation (Wade et al. 2012). Samples below $46.24 \mathrm{~m}$ contain extremely well preserved planktonic foraminifera, whereas samples from above are characterized by high lithification and deterioration of the planktonic foraminiferal preservation with calcite overgrowth. We tentatively assigned a duration of $\sim 190 \mathrm{kyr}$ for this hiatus (Fig. 7, Wade et al. 2012).

Within Miller et al.'s (2008) BRB sequence we record another sequence boundary (indicated by the transition from dominant Spiniferites cpx to dominant Homotryblium cpx) at a level where the latter authors assigned a tentative MFS, based on the continuous presence of glauconite up to that level $(45.2 \mathrm{~m}$ core depth, Fig. 6). The overlying TST is then accompanied 
by abundant Phthanoperidinium spp., a peridinioid taxon indicative of nutrient-rich conditions that may also occur in outer neritic conditions (Firth 1996). The upper part of the BRB-sequence is represented by a relatively complete HST, as indicated by elevated BIT values, high abundance of terrestrial palynomorphs and dinocyst assemblages dominated by Homotryblium cpx and Delfandrea - Wetzeliella cpx (Figs. 3, 5).

The sequence boundary between the BRB-sequence and the MMG-sequence is clearly reflected by a change from assemblages dominated by Homotryblium cpx to Spiniferites cpx in the lowermost sample corresponding to the MMG sequence (Fig. 5). This sequence boundary possibly corresponds to the second major isotope step in the early Oligocene, Oi-1 a (Katz et al. 2008, Miller et al. 2008). Interestingly, we did not record any cooling using $\mathrm{TEX}_{86}$ across this level (Fig. 5).

The Mint Spring Fm. and Marianna fm. and Glendon fm. comprise a thick $(40.5-15.5 \mathrm{~m})$ succession at $\mathrm{SSQ}$. The base of the Marianna $\mathrm{fm}$. is placed at a change to a glauconitic micrite at $39.99 \mathrm{~m}$ (Miller et al. 2008). They interpret this contact as the MFS of the Mint Spring-Marianna sequence, based on deep biofacies (indicative of $\sim 125 \mathrm{~m}$ water depth). Above this, the Marianna Formation shallows upsection from the Siphonina ( $\sim 100 \mathrm{~m}$ water depth) to the Hanzawaia biofacies ( $\sim 75 \mathrm{~m}$ water depth). Across the MMGsequence, the dinocyst assemblages are relatively uniform, dominated by typically outer neritic gonyaulacoid taxa. At the MFS-level, we record a highly diverse assemblage composing Cleistosphaeridium cpx, Homotryblium cpx, Spiniferites cpx and even Wetzeliella-Delfandrea cpx. Up-section, relatively offshore components become increasingly abundant. We therefore tentatively place the MFS further upsection (29 $\mathrm{m}$ core depth). The environmental interpretation of the Glendon Limestone fm. (15.54-18.14 m) is problematic on the basis of lithostratigraphy and biofacies-analysis (Miller et al. 2008). The unit is represented by an indurated limestone. In fact, Tew (1992) regarded the Glendon Limestone as the highstand deposit of the underlying sequence and placed a sequence boundary at its top. In contrast, Baum and Vail (1988) interpreted it as the low-stand deposits of the overlying sequence. Our study shows that this part of the succession is overwhelmingly dominated by terrestrial palynomorphs and does not constitute marine palynomorphs. Also the BIT-values are elevated $(0.6-0.8)$. There is no evidence that the HSTs become aerially exposed at SSQ, which tentatively implies that the Glendon Limestone probably corresponds the LST of an overlying sequence. A major facies shift occurs at the top of the Glendon Fm. in the core hole (Tew 1992, Miller et al. 2008) and corresponds to the sequence boundary at the top of the Glendon Formation. Integration of magneto- and biostratigraphic data indicates a significant hiatus (0.8-1.3 myr) between the Glendon fm. and Byram Fm. (Miller et al. 2008) that correlates to the Oi-1 b shift (Miller et al. 2008).

There is a relationship between the dinocyst-inferred coastal proximity interpretation and the dinocyst diversity, H(s) (Fig. 6). Across transitions from HSTs to TSTs, i. e., in associations indicative of decreasing coastal proximity (or rising relative sea-level) diversity decreases. As a consequence, MFSs correspond to diversity minima. This is largely ascribed to the fact that these distal associations, dominated by Spiniferites cpx are relatively low in diversity. However, this group comprises numerous species entities, which is not accounted for. Hence, applying diversity-based indices in dinoflagellate cyst paleoecology is not always straightforward (see e. g., Pross and Schmiedl 2002).

\subsubsection{Stratigraphic and paleoenvironmental distribution of selected dinocyst taxa}

A few dinocyst taxa have restricted ranges at SSQ (Fig. 8), some of which have been shown elsewhere to have paleoenvironmental and/or biostratigraphic significance.

Dinocysts belonging to the Subfamily of the Wetzelielloideae occur in high abundance in the North Twistwood Clay Fm., correlative to Chron C16 (i.e., below $58 \mathrm{~m}$ core depth). These mainly comprise Charlesdowniea clathrata and Rhombodinium draco. This may in part be explained by the fact that this interval represents a relatively complete HST. However, such high abundances do not occur further upsection, neither in association with the preserved HSTs of the lower Oligocene (e.g., as part of the MMGsequence). In fact, whereas C. clathrata sporadically occurs up-section, $R$. draco has a stratigraphically highest occurrence (HO) just above the interval with high abundance (53.2 $\mathrm{m}$ core depth). This HO is recorded consistently throughout the Gulf Coast Region (Jaramillo and Oboh-Ikuenobe 1999). R. draco is known to range well into the Oligocene in the North Sea and Western Tethys (Williams et al. 1993, Van Simaeys et al. 2004, Pross et al. 2009). Hence, this HO appears stratigraphically older on the Alabama Shelf 
compared to other regions. We recorded a short interval with presence of Rhombodinium perforatum (61.1-58.2 $\mathrm{m}$ core depth). This taxon is not reported by Jaramillo and Oboh-Ikuenobe (1999), likely due to their limited resolution and the short stratigraphic range of the taxon. Its published stratigraphical lowest occurrence (LO) is in the late Bartonian to early Priabonian (38-36 Ma) (Mudge and Bujak 1996, Heilman-Clausen and Van Simaeys 2005, Iakovleva and Heilmann-Clausen 2010) and its HO lies very close to the E/O-boundary (Williams et al. 1993). Hence, its range is substantially shorter at SSQ.

Melitasphaeridium pseudorecurvatum has a reported HO within Chron C15 r ( 35.4-35 Ma) in the Tethys (Brinkhuis and Biffi 1993) and the North Atlantic (Eldrett et al. 2004). At SSQ, M. pseudorecurvatum has a $\mathrm{HO}$ at the sequence boundary between the MNT and $\mathrm{CP}$ sequences, which indeed corresponds to Chron C15r. This illustrates that the HO of M. pseudorecurvatum is relatively synchronous across a large area. The same holds for the FO of Reticulatosphaera actinocoronata, which first appears at the MNT - CP sequence boundary and ranges throughout the top of section. Its reported LOs for the Tethys, Australia and North Atlantic are also infra Chron C15 r (Williams et al. 1993, Brinkhuis et al. 2003, Eldrett et al. 2004).

Lentinia serrata is a species that is abundant in the North Atlantic and high northern latitudes from the middle Eocene ( 46-40 Ma) onwards (Bujak 1984, Sangiorgi et al. 2008). It is reported to occur in the low latitudes of the western Tethys in the late Eocene, close to the EOT-1 shift, likely as a result of progressive climatic cooling (Brinkhuis and Biffi 1993, Houben et al. 2011), allowing this boreal taxon to persist at low latitudes. At SSQ the introduction of L. serrata is substantially earlier, just below the MNT - CP sequence boundary. Also, its $\mathrm{HO}$ appears to be earlier than in the Western Tethys (Chron C12 r, 32.5 Ma, Pross et al. 2009). In the study by Jaramillo and ObohIkuenobe (1999), occurrences of this taxon are likely erroneously considered reworked.

Schematophora speciosa has a narrow range at SSQ, from the MNT - CP sequence boundary (Chron C16, 35.4 Ma) to a level within Chron C15 r dated $\sim 35 \mathrm{Ma}$. Its $\mathrm{LO}$ and $\mathrm{HO}$ are well-constrained in the Tethys (Brinkhuis and Biffi 1993) and in Australia (Sluijs et al. 2003). It ranges between Chrons C16n. $1 \mathrm{n}$ and C16n.2n in Australia and just up into Chron C15 r in the Western Tethys. Hence it appears to go extinct consistently earlier in the high southern latitudes. Hemiplaciphora semilunifera, a taxon that is morpho- logically closely related to $S$. speciosa, has a HO in Chron C16n.2 $\mathrm{n}$ in Australia (Sluijs et al. 2003) and has a longer range in Italy, there approximating the level corresponding to the EOT-1 shift (Brinkhuis and Biffi 1993, Houben et al. 2011). At SSQ, specimens of $H$. semilunifera are present from the MNT-CP sequence boundary and range up to a level within Chron $\mathrm{C} 13 \mathrm{r}$ $(33.7 \mathrm{Ma})$, close to the EOT-1 shift. It thus appears that HOs of both related taxa are persistently younger in the low-latitude settings of the GoM and the Western Tethys. The HO of the H. semilunifera accompanies the EOT-1 shift and may as such be directly related to climatic deterioration.

At the EOT-1 level, Impagidinium velorum has three spot occurrences. I. velorum has been described from the upper Eocene of the Bering Sea (Bujak 1984) and has been found to occur in lower latitudes during phases of cooling (Brinkhuis and Biffi 1993). These occurrences may as such also relate to the EOT-1 cooling at SSQ.

Pentadinium alabamaensis (Quaijtaal and Brinkhuis 2012) has a spot occurrence in a stratum just below the Oi-1 hiatus (33.57 Ma). It has a range of consistent occurrences throughout Chron C13n. More specifically, it is abundant through the HST of the BRB-sequence. It has been suggested that its remarkable morphology is the consequence of reduced salinity, since it is associated with increased terrestrial palynomorphs and fresh-water tolerant and/or euryhaline dinocyst taxa including the Homotryblium cpx. Its biogeographic distribution is to date restricted to the GoM (Pentadinium sp. A in Jaramillo and ObohIkuenobe 1999) and appears stratigraphically confined to Chron C13n.

Fig. 8. Chronostratigraphic interpretation of the sequences at SSQ. The interpretation of Miller et al. (2008) and this study are compared with the main features of deep-sea high resolution $\delta^{18} \mathrm{O}$-records from ODP Site 1218 (equatorial Pacific, Coxall et al. 2005) and ODP Site 744 (Southern Ocean, Zachos et al. 1996). The benthic foraminiferal $\delta^{18} \mathrm{O}-$ record from the SSQ is also scaled to the current age-model for comparison. All ages are relative to the time scale of (Berggren et al. 1995 and Wade et al. 2011, for the foraminifer-zonation) to warrant direct comparison with previous studies on this section. SSTs reconstructed using TEX ${ }_{86}{ }^{\mathrm{H}}$ (partly after Wade et al. 2012) are plotted alongside the distribution of some dinocyst taxa discussed in this study. Thick lines indicate that taxa occur by $>30 \%$. Dashed lines indicate that the distribution of taxa is probably stratigraphically extended. The EOT-1 stands out as the main period of cooling and biotic turnover. 


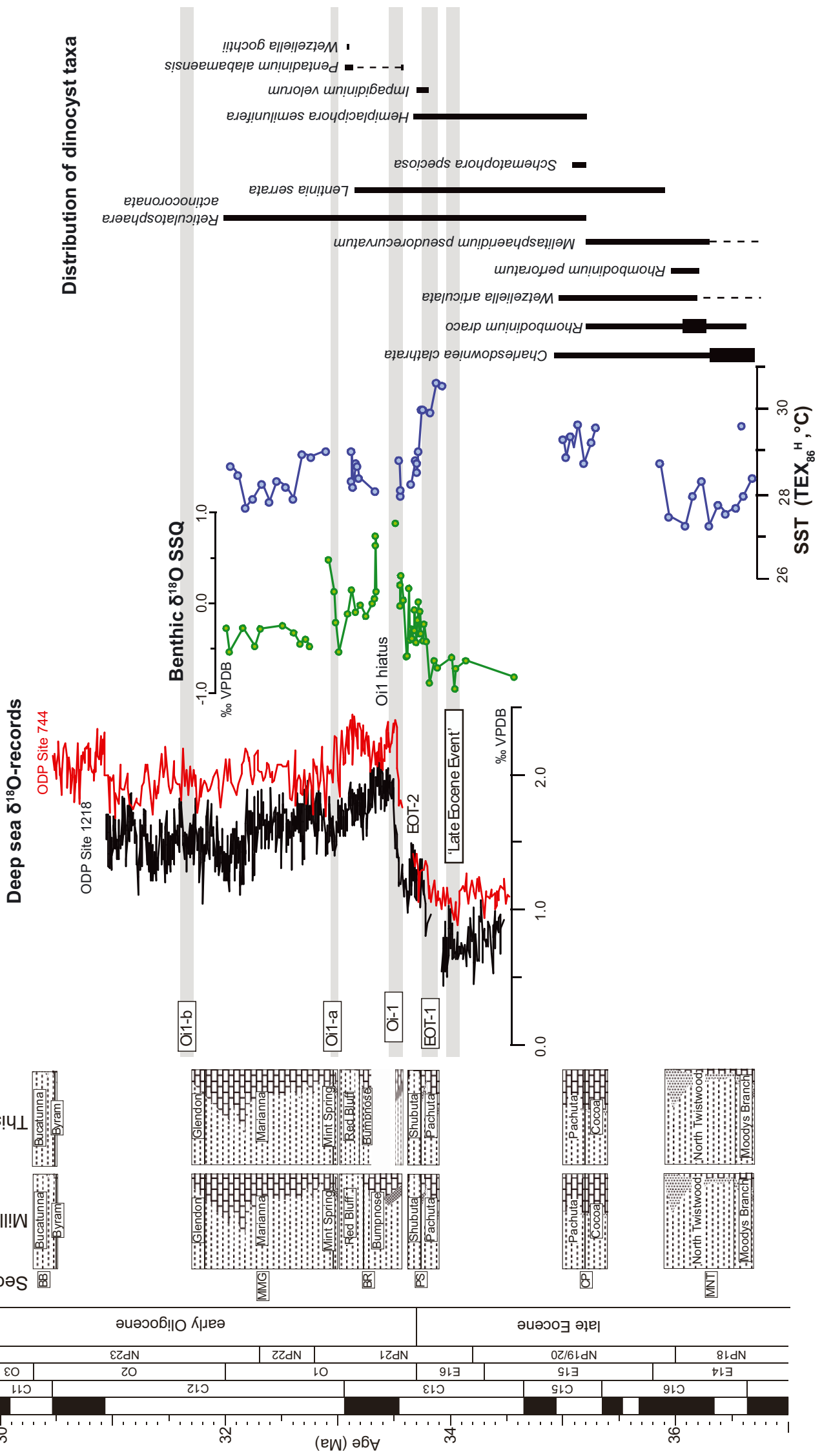


Two specimens of Wetzeliella gochtii have been recorded in strata corresponding to the upper part of Chron C13n. The LO of W. gochtii has in the Western Tethys been firmly dated to the lower part of Chron C12 r (Pross et al. 2009). However, in the North Atlantic, W. gochtii has a LO in the upper part of Chron C13 n (Eldrett et al. 2004), which is more akin to the pattern observed at SSQ.

\section{Discussion}

The following section discusses the environmental evolution across and significance of the various 'steps' or 'shifts' associated with the EOT, in context of the data presented in this study. This follows a chronological order from older to younger.

In deep-sea late Eocene records, a transient $\delta^{18} \mathrm{O}$ increase is recorded prior to the EOT interval (Katz et al. 2008, Coxall and Wilson 2011, Pusz et al. 2011). This increase has been referred to as the "late Eocene event' (Katz et al. 2008, Fig. 8). It has been interpreted to represent a transient initial glaciation of Antarctica (Katz et al. 2008, Peters et al. 2010). The sequence boundary between the Cocoa Sand and Pachuta Marl (CP-PS) sequences is associated with a substantial hiatus (see also Miller et al. 2008) and may be timeequivalent with this 'late Eocene event'. The SSQrecord may thus support that this 'late Eocene event' represents a transient sea level fall, arguably forced by Antarctic ice-growth. We emphasize that precise correlation between any late Eocene sea level fall and transient phenomena in high resolution foraminiferal $\delta^{18} \mathrm{O}$-records remains very difficult, if not impossible, without independent stratigraphic tools (such as coeval magnetic reversals). For instance, a conspicuous sea level fall before the EOT-1 and Oi-1 was not recorded in the Priabonian type-section in northern Italy (Houben et al. 2011). Furthermore, the rate and magnitude of change in high-resolution $\delta^{18} \mathrm{O}$ records suggests that any glacial advances that might have occurred on Antarctica on the immediate run-up to the EOT must have been comparatively small and transient in nature. Hence, large ice sheets were not sustained until the early Oligocene (see also Coxall and Wilson 2011).

We did identify a sequence boundary as a consequence of sea level fall in association with the first shift (EOT-1; i. e., the (para)sequence boundary in the upper part of the Pachuta Member of the Yazoo Formation, $49.1 \mathrm{~m}$ core depth). Wade et al. (2012) and Evans et al.
(2016) demonstrated that at SSQ, the EOT-1 shift represented a $4-6{ }^{\circ} \mathrm{C}$ sea surface cooling. Similar cooling patterns in Tanzania (Lear et al. 2008), Italy (Houben et al. 2011) and deep-sea records (Bohaty et al. 2012) corroborate these inferences. Hence, the EOT-1 stands out as a phase of substantial cooling and at least some transient glaciation. Perhaps connected, the EOT-1 shift is also accompanied by migrations and turnover in plankton communities in different groups. Extinction is reported among the larger benthic foraminifers of the Discocyclinidae (Adams et al. 1986, Pearson et al. 2008), the planktonic foraminifers (i. e., Turborotalita cerroazuelensis group, Wade and Pearson 2008) calcareous nannofossils (Dunkley Jones et al. 2008) and ostracods (Yamaguchi et al. 2014). At SSQ we now document turnover among dinoflagellates in the GoM. First, several relatively long ranging dinocyst taxa such as Rhombodinium draco and $\mathrm{Me}$ litasphaeridium pseudorecurvatum disappear in the late Eocene, potentially as a consequence of progressive late Eocene cooling. Coincident with these extinctions, a boreal taxon, Lentinia serrata (Bujak 1984) is introduced in the GoM, possibly as a consequence of progressive cooling. Cooling at the EOT-1 shift also coincides with the extinction of Hemiplaciphora semilunifera and the EOT-1 marks the introduction of Impagidinium velorum, a boreal cold-water indicator (Brinkhuis and Biffi 1993). A similar phenomenon is observed in central Italy where $H$. semilunifera disappears close to the EOT-1 level and introductions of $I$. velorum start to recur (Houben et al. 2011).

The interval between the EOT-1 and Oi-1 isotope shifts, often termed the 'EOT-plateau', straddles the current E/O-boundary sensu stricto, as based on the $\mathrm{HO}$ of the hantkeninid foraminifers (see Premoli Silva and Jenkins 1993) and is characterized by a highly variable overall decrease in $\delta^{18} \mathrm{O}$ values (Zachos et al. 1996, Coxall and Wilson 2011, see Fig. 8). Straddling this plateau, Katz et al. (2008) noted another $\delta^{18} \mathrm{O}$ increase in the records from SSQ and the central Pacific. The increased resolution of the $\delta^{18} \mathrm{O}$-record at the central Pacific site (Coxall and Wilson 2011) however, does not strengthen the case for a distinct third $\delta^{18} \mathrm{O}$-shift, indicating that the "EOT-2" interpreted from the GoM shelf record corresponds to an interval of amplitude variation change not seen in the deep sea records. Our dinocyst-based sequence stratigraphy elucidates the plateau-phase at SSQ as: (I) a transgression following the EOT-1. This implies that sea level gradually rose during this 'EOT - plateau', and therefore that some of the Antarctic ice sheet that 
accumulated during the EOT-1 retreated. A correlative TST and MFS are recorded in the Priabonian Type Section in Italy (Houben et al. 2011). (II) A subsequent regression culminated in a sequence boundary at $46.9 \mathrm{~m}$ core depth. This sequence boundary may correspond to one of the high-order cryosphere variations that may be inferred from high-resolution foraminiferal $\delta^{18} \mathrm{O}$ records (e. g., the EOT-2 shift; Miller et al. 2009). Such a pattern of high order cryosphere dynamics after initial glacial expansion is in line with the hypothesized role of strong nonlinear feedbacks in ice sheet mass balance and stability (Oerlemans 2002, DeConto and Pollard 2003, Gomez et al. 2010). Above this sequence boundary we record a distinct MFS also illustrating the transient nature of cryosphere dynamics.

Rather than at the PS-BRB (46.9 m core depth) sequence boundary of Miller et al. (2008), the Oi-1 shift is manifested at SSQ as a hiatus further up-section (46.1 m core depth). We tentatively estimate this hiatus to capture the first $190 \mathrm{kyr}$ of Chron C13 n (see also Wade et al. 2012). As a consequence, only the initial increase in $\delta^{18} \mathrm{O}$-values of the Oi-1 is recorded. Backstripping studies from the New Jersey shelf suggest a $\sim 55 \mathrm{~m}$ sea level fall corresponding to Oi-1 (Miller et al. 2009 and references therein), an estimate that is in accordance with inferences of microfacies analysis from the Priabonian Type-section (Setiawan 1983, Houben et al. 2011). This interpretation suggests that the Oi-1 isotope shift is not completely recovered at SSQ. Hence, neither the benthic foraminifera $\delta^{18} \mathrm{O}$ increase nor the corresponding temperature change deduced from the $\mathrm{Mg} / \mathrm{Ca}$-ratios of benthic foraminifera at SSQ by Katz et al. (2008) are representative of the complete temperature and ice-volume evolution across the EOT. This discrepancy may aid to explain part of the paradigm proposed by Katz et al. (2008), that an ice-volume that is substantially larger than modern was stored on Antarctica across the EOT and Oi-1 specifically.

Across the Oi-1 hiatus, planktonic $\mathrm{Mg} / \mathrm{Ca}$ and $\mathrm{TEX}_{86}$ records do not show evidence of substantial cooling (Wade et al. 2012). Instead, oxygen isotope ratios measured on different planktonic foraminifer taxa argue for increased seasonality across the Oi-1 shift. This phenomenon has also been recorded in fish otoliths from the GoM, which suggested a cooling of winter temperatures by $4{ }^{\circ} \mathrm{C}$, but no major mean annual temperature drop (Ivany et al. 2000). Hence, it appears that the Oi-1 shift primarily represented a major increase in Antarctic ice-volume that in the GoM resulted in sea level fall and seasonal cooling. Remarkably, no major reorganizations are observed in the dinocyst assemblages or their turnover across the Oi-1. A similar pattern is recognized in many calcareous microfossil groups, for which extinctions and turnover preceded maximum glacial conditions at Oi-1, occurring $\sim 200$ kyr earlier around the EOT-1 (Pearson et al. 2008). We therefore speculate that the relatively rapid cooling exerted a stronger control on the biotic turnover in lowlatitude shelf ecosystems than related sea level fall.

Based on the early $\delta^{18} \mathrm{O}$-records from the Southern Ocean (Miller et al. 1991, Zachos et al. 1996), it was proposed that the interval directly following the Oi- 1 is a "zone" of maximum $\delta^{18} \mathrm{O}$ values that represents the so-called Early Oligocene Glacial Maximum (EOGM, Liu et al. 2004). Originally, before high-resolution records were generated, the Oi-1 was known to represent this zone (Miller et al. 1991), but now the Oi-1 is used to refer to the shift into the the EOGM. Ultrahigh resolution $\delta^{18} \mathrm{O}$ records (cf. Coxall and Wilson 2011) support the concept of two distinct glacial maxima within magnetochron $\mathrm{C} 13 \mathrm{n}$ (referred to as Oi-1 a and Oi-1 b, after Zachos et al. 1996). The sequence stratigraphic record from SSQ does in fact discern a clear sea level sequence throughout Chron $\mathrm{C} 13 \mathrm{n}$, which is however characterized by relatively complete preservation of the HST. This suggests that sea level variability through the EOGM was limited, indicating a period of ice-sheet stability immediately after its establishment.

Perhaps confusingly, the term 'Oi-1 a' has been introduced by Pekar and Miller (1996, see also Miller et al. 2008) to refer to a subsequent increase in $\delta^{18} \mathrm{O}$ at the top of Chron C13 n ( 33 Ma, see e. g., Coxall and Wilson 2011). This level (40.1 m core depth) marks a clear sequence boundary and may as such be related to another intensification of cryosphere dynamics or alternatively, a local phenomenon. Above that level a relatively expanded and remarkably complete succession, characterized by a relatively deep (outer neritic) biofacies is recovered (Miller et al. 2008). Across this interval, which corresponds to Chron $\mathrm{C} 12 \mathrm{r}$, the high-resolution records indicate $\delta^{18} \mathrm{O}$-values that are typically less positive than for the EOGM (Fig. 8). This may imply that a portion of the icevolume on Antarctica that accumulated during the EOGM has melted. Towards the top of the MMGsequence, the section at SSQ becomes more proximal and shallower, culminating in a sequence boundary that correlates to the Oi-1 b shift of Pekar and Miller (1996, $31 \mathrm{Ma})$. Both these Oi-1 a and Oi-1 b shifts are 
much less abrupt and can better considered isotope zones. Collectively, in the GoM, far away from the waxing and waning of the Antarctic ice sheets, sequence stratigraphic patterns can be reconciled with high-resolution $\delta^{18} \mathrm{O}$-change, confirming that ice-volume changes are important contributors to these records.

\section{Conclusions}

Dinocyst assemblages show pronounced variations in the upper Eocene - lower Oligocene succession of the SSQ corehole. These variations are indicative of changes in coastal proximity as a consequence of local sea level change. This allowed us to refine the sequence stratigraphic interpretation for the SSQ corehole. The identification of three sequence boundaries; between the (I) upper Eocene MNT and CP sequences, (II) the lower Oligocene BRB and MMG sequences and (III) MMG and BB sequences are in agreement with previous studies. High-resolution investigation of the EOT interval now allowed us to in detail to elucidate sea level variability during the initiation of Antarctic glaciation. We identify a 'new' sequence boundary at a level corresponding to the EOT-1 or precursor isotope shift. This suggests the EOT-1 shift is the combined effect of cooling and relatively small sea level fall $(\sim 20 \mathrm{~m})$.

The sequence boundary between the PS and the $\mathrm{BRB}$ sequences was previously interpreted to represent the sea level fall as a consequence of ice buildup related to the Oi-1 shift. However, the sequence boundary is located at a level corresponding to reversed magnetic polarity, whereas the Oi-1 is calibrated to the base of the normal polarity Chron $\mathrm{C} 13 \mathrm{n}$. Rather, we identified a hiatus near the base of Chron C13 n, within the Bumpnose Limestone, capturing the Oi-1 isotope shift. This provides a plausible explanation for the isotopic records from SSQ, in which a sustained increase in $\delta^{18} \mathrm{O}$ is absent. The hiatus is in line with a postulated sea level fall of $\sim 50-75 \mathrm{~m}$ associated with the Oi-1.

Furthermore, we show that the EOT-1 shift represents a phase of migration and extinction of temperature sensitive dinoflagellates, whereas the Oi- 1 shift is not particularly accompanied by major biotic turnover. Hence, it increasingly appears that major cooling and at least some Antarctic ice buildup preceded the rapid inception of full-scale Antarctic glaciation in the earliest Oligocene (Oi-1).
Acknowledgements. AJPH and HB acknowledge Statoil (now Equinor) for funding. BW was supported by UK Natural Environment Research Council (NERC) reference number NE/G014817. Kenneth Miller is acknowledged for providing access to the core samples.

\section{References}

Adams, C. G., Butterlin, J., Samanta, B. K., 1986. Larger foraminifera and events at the Eocene-Oligocene boundary in the Indo-West region. In: Pomerol, C., Premoli, Silva, I. (Eds.), Terminal Eocene Events. Elsevier, Amsterdam, 237-252.

Baum, G. R., Vail, P. R., 1988. Sequence stratigraphic concepts applied to Paleogene outcrops, Gulf and Atlantic basins, Sea level changes: an integrated approach. SEPM Special Publication 42, 309-327.

Berggren, W. A., Kent, D. V., Swisher, C. C., Aubry, M. P., 1995. A revised Cenozoic geochronology and chronostratigraphy. In: Berggren, W. A. et al. (Eds.), Geochronology, time scales and global stratigraphic correlation. SEPM Special Publication 54, 129-212.

Bohaty, S. M., Zachos, J. C., Delaney, M. L., 2012. Foraminiferal $\mathrm{Mg} / \mathrm{Ca}$ evidence for Southern Ocean cooling across the Eocene-Oligocene transition. Earth Planetary Science Letters 317, 251-261.

Bradford, M. R., Wall, D., 1984. The distribution of recent organic-walled dinoflagellate cysts in the Persian Gulf, Gulf of Oman, and northwestern Arabian Sea. Paleontographica 192, 16-84.

Brinkhuis, H., 1994. Late Eocene to Early Oligocene dinoflagellate cysts from the Priabonian type-area (Northeast Italy): biostratigraphy and paleoenvironmental interpretation. Palaeogeography, Palaeoclimatology, Palaeoecology 107, 121-163.

Brinkhuis, H., Biffi, U., 1994. Dinoflagellate cyst stratigraphy of the Eocene/Oligocene transition in central Italy. Marine Micropaleontology 22, 131-183.

Brinkhuis, H., Sengers, S., Sluijs, A., Warnaar, J., Williams, G. L., 2003. Latest Cretaceous-Earliest Oligocene and Quaternary Dinoflagellate cysts, ODP Site 1172, East Tasman Plateau. In: Exon, N. F., Kennett, J. P., Malone, M. J. (Eds.), Proceedings of the Ocean Drilling Program, Scientific Results 189.

Bujak, J.P., 1984. Cenozoic dinoflagellate cysts and acritarchs from the Bering Sea and northern North Pacific, D. S. D. P. Leg 19. Micropaleontology 30, 180-212.

Coxall, H. K., Wilson, P. A., 2011. Oligocene glaciation and productivity in the eastern equatorial Pacific: Insights into global carbon cycling. Paleoceanography 26.

Coxall, H. K., Wilson, P. A., Pälike, H., Lear, C. H., Backman, J., 2005. Rapid stepwise onset of Antarctic glaciation and deeper calcite compensation in the Pacific Ocean. Nature 433, 53-57.

Crouch, E. M., Brinkhuis, H., 2005. Environmental change across the Paleocene-Eocene transition from eastern New 
Zealand: A marine palynological approach. Marine Micropaleontology 56, 138-160.

DeConto, R. M., Pollard, D., 2003. Rapid Cenozoic glaciation of Antarctica induced by declining atmospheric $\mathrm{CO}_{2}$. Nature 421, 245-249.

Dockery, D. T., 1982. Lower Oligocene Bivalvia of the Vicksburg Group. Mississippi Department of Natural Resources Bureau Bulletin 123, 1-261.

Dunkley Jones, T., Bown, P. R., Pearson, P. N., Wade, B. S., Coxall, H. K., Lear, C.H., 2008. Major shifts in calcareous phytoplankton assemblages through the EoceneOligocene transition of Tanzania and their implications for low-latitude primary production. Paleoceanography 23.

Eldrett, J. S., Greenwood, D. R., Harding, I. C., Huber, M., 2009. Increased seasonality through the Eocene to Oligocene transition in northern high latitudes. Nature 459, 69-973.

Eldrett, J. S., Harding, I. C., Firth, J. V., Roberts, A. P., 2004. Magnetostratigraphic calibration of Eocene-Oligocene dinofagellate cyst biostratigraphy from the NorwegianGreenland Sea. Marine Geology, 204, 91-127.

Evans, D., Wade, B. S., Henehan, M., Erez, J., Muller, W., 2016. Revisiting carbonate chemistry controls on planktic foraminifera $\mathrm{Mg} / \mathrm{Ca}$ : implications for sea surface temperature and hydrology shifts over the Paleocene-Eocene Thermal Maximum and Eocene-Oligocene Transition. Climate of the Past 11, 3143-3185.

Fensome, R.A., MacRae, R. A., Williams, G. L., 2008. DINOFLAJ2, Version 1, American Association of Stratigraphic Palynologists Foundation, Data Series \# 1Available online at: http://www.dinoflaj.smu.ca.

Fensome, R. A., Taylor, F. J. R., Norris, G., Sarjeant, W. A. S., Wharton, D. I., Williams, G. L., 1993. A Classification of Modern and Fossil Dinoflagellates. Micropaleontology Press Special papers in Paleontology 7, 351.

Firth, J. V., 1996. Upper middle Eocene to Oligocene dinoflagellate biostratigraphy and assemblage variations in hole 913B, Greenland Sea. In: Thiede, J., Myrhe, A. M., Firth, J. V., Johnson, G. L., Ruddiman, W. F. (Eds.), Proceedings of the Ocean Drilling Program. Scientific Results, 203-242.

Gomez, N., Mitrovica, J. X., Huybers, P., Clark, P. U., 2010. Sea level as a stabilizing factor for marine-ice-sheet grounding lines. Nature Geoscience 3, 850-853.

Hazel, J. E., Mumma, M. D., Huff, W. J., 1980. Ostracode biostratigraphy of the lower Oligocene (Vicksburgian) of Mississippi and Alabama. Transactions of the Gulf Coast Association of Geological Societies 30, 361-401.

Heilman-Clausen, C., Van Simaeys, S., 2005. Dinoflagellate cysts from the Middle Eocene to ?lowermost Oligocene in the Kysing Borehole, Central Danish Basin. Palynology 29, 43-204.

Hopmans, E. C., Weijers, J. W. H., Schefuss, E., Herfort, L., Sinninghe Damsté, J.S., Schouten, S., 2004. A novel proxy for terrestrial organic matter in sediments based on branched and isoprenoid tetraether lipids. Earth \& Planetary Science Letters 224, 107-16.
Houben, A. J. P., van Mourik, C. A., Montanari, A., Coccioni, R., Brinkhuis, H., 2011. The Eocene - Oligocene transition: Changes in sea level, temperature or both? An exercise in global correlation. Palaeogeogr., Palaeoclimatol., Palaeoecol. 335-336, 5-83.

Iakovleva, A. I., Heilmann-Clausen, C., 2010. Eocene dinoflagellate cyst biostratigraphy of research borehole 011BP, Omsk Region, southwestern Siberia. Palynology 34, 195-232.

Ivany, L. C., Patterson, W. P., Lohmann, K. C., 2000. Cooler winters as a possible cause of mass extinctions at the Eocene/Oligocene boundary. Nature 407, 887.

Jaramillo, C. A., Oboh-Ikuenobe, F. E., 1999. Sequence stratigraphic interpretations from palynofacies, dinocyst and lithological data of Upper Eocene-Lower Oligocene strata in southern Mississippi and Alabama, U.S. Gulf Coast. Palaeogeogr., Palaeoclimatol., Palaeoecol. 145, 259-302.

Katz, M.E., Miller, K. G., Wright, J.D., Wade, B. S., Browning, J. V., Cramer, B.S., Rosenthal, Y., 2008. Stepwise transition from the Eocene greenhouse to the Oligocene icehouse. Nature Geoscience 1, 329-334.

Kobashi, T., Grossman, E.L., Yancey, T.E., Dockery, D. T. I., 2001. Reevaluation of conflicting Eocene tropical temperature estimates: Molluskan oxygen isotope evidence for warm low latitudes. Geology 29, 983-986.

Lear, C.H., Bailey, T.R., Pearson, P.N., Coxall, H. K., Rosenthal, Y., 2008. Cooling and ice growth across the Eocene-Oligocene transition. Geology 36, 251-254.

Lewis, J., Rochon, A., Ellegaard, M., Mudie, P., Harding, I., 2001. The cyst-theca relationship of Bitectatodinium tepikiense (Dinophyceae). Eur. J. Phycol. 36, 137-146.

Liu, Z., Tuo, S., Zhao, Q., Cheng, X., Huang, W., 2004. Deep-water earliest Oligocene glacial maximum (EOGM) in South Atlantic. Chinese Science Bulletin 49, 2190-2197.

Loutit, T. S., Hardenbol, J., Vail, P. R., Baum, G. R., 1988. Condensed sections: the key to age determination and correlation of continental margin sequences, Sea level Changes: An Integrated Approach. Spec. Publ SEPM 42, 183-213.

Mancini, E. A., 2000. Sequence stratigraphy and chronostratigraphy of upper Eocene and lower Oligocene strata, Eastern Gulf Coastal Plain. Gulf Coast Association of Geological Societies Transactions Volume L, 379-388.

Mancini, E. A., Tew, B. H., 1991. Relationships of Paleogene stage and planktonic foraminiferal zone boundaries to lithostratigraphic and allostratigraphic contacts in the eastern Gulf Coastal Plain. The Journal of Foraminiferal Research 21, 48.

Mertens, K. N., Ribeiro, S., Bouimetarhan, I., Caner, H., Combourieu Nebout, N., Dale, B., De Vernal, A., Ellegaard, M., Filipova, M., Godhe, A., Goubert, E., GrØsfjeld, K., Holzwarth, U., Kotthoff, U., Leroy, S. A. G., Londeix, L., Marret, F., Matsuoka, K., Mudie, P. J., Naudts, L., Peña-Manjarrez, J., Persson, A., Popescu, S., Pospelova, V., Sangiorgi, F., van der Meer, Marcel T. J., Vink, A., Zonneveld, K. A.F., Vercauteren, D., 
Vlassenbroeck, J., Louwye, S., 2009. Process length variation in cysts of a dinoflagellate, Lingulodinium machaerophorum, in surface sediments: Investigating its potential as salinity proxy. Mar. Micropaleontol. 70, 54-69.

Miller, K. G., Browning, J. V., Aubry, M.P., Wade, B. S., Katz, M. E., Kulpecz, A. A., Wright, J. D., 2008. EoceneOligocene global climate and sea level changes: St. Stephens Quarry, Alabama. GSA Bulletin 120, 34-53.

Miller, K. G., Kominz, M. A., Browning, J. V., Wright, J. D., Mountain, G. S., Katz, M.E., Sugarman, P. J., Cramer, B. S., Christie-Blick, N., Pekar, S. F., 2005. The Phanerozoic Record of Global Sea level Change. Science 310, 1293-1298.

Miller, K. G., Thompson, P. R., Kent, D. V., 1993. Integrated Late Eocene-Oligocene stratigraphy of the Alabama coastal plain: Correlation of hiatuses and stratal surfaces to glacioeustatic lowerings. Paleoceanography 8, 313-331.

Miller, K. G., Wright, J. D., Fairbanks, R. G., 1991. Unlocking the Ice House Oligocene-Miocene Oxygen Isotopes, eustasy and Margin Erosion. J. Geophys. Res. 96, 6829-6848.

Miller, K. G., Wright, J.D., Katz, M.E., Wade, B.S., Browning, J. V., Cramer, B. S., Rosenthal, Y., 2009. Climate threshold at the Eocene-Oligocene transition: Antarctic ice sheet influence on ocean circulation. Geological Society of America Special Papers 452, 169-178.

Milne, G. A., Mitrovica, J. X., 2008. Searching for eustasy in deglacial sea level histories. Quaternary Science Reviews 27, 2292-2302.

Mudge, D. C., Bujak, J. P., 1996. An integrated stratigraphy for the Paleocene and Eocene of the North Sea. Geological Society of London Special Publications 101, 91.

Oerlemans, J., 2002. On glacial inception and orography. Quaternary International 95, 5-10.

Pasley, M. A., Hazel, J.E., 1990. Use of organic petrology and graphic correlation of biostratigraphic data in sequence stratigraphic interpretations: Examples from the Eocene-Oligocene boundary section, St, Stephens Quarry, Alabama. Gulf Coast Association of Geological Societies Transactions 40, 661-683.

Patten, B. C., 1962. Species diversity in net phytoplankton of Raritan Bay. Yale University Press.

Pearson, P. N., McMillan, I. K., Wade, B. S., Dunkley Jones, T., Coxall, H. K., Bown, P. R., Lear, C. H., 2008. Extinction and environmental change across the Eocene-Oligocene boundary in Tanzania. Geology 36, 179-182.

Pekar, S., Miller, K. G., 1996. New Jersey Oligocene "Icehouse" sequences (ODP Leg 150X) correlated with global $\delta^{18} \mathrm{O}$ and Exxon eustatic records. Geology 24, 567-570.

Peters, S. E., Carlson, A. E., Kelly, D. C., Gingerich, P. D., 2010. Large-scale glaciation and deglaciation of Antarctica during the Late Eocene. Geology 38, 723-726.

Premoli Silva, I., Jenkins, G. D., 1993. Decision on the Eocene-Oligocene boundary stratotype. Episodes 16, 379-379.

Pross, J., Brinkhuis, H., 2005. Organic-walled dinoflagellate cysts as paleoenvironmental indicators in the Paleogene; a synopsis of concepts. Palaeontologische Zeitschrift, Band Band 79, 53-59.

Pross, J., Houben, A. J. P., van Simaeys, S., Williams, G. L., Kotthoff, U., Coccioni, R., Wilpshaar, M., Brinkhuis, H., 2009. Umbria-Marche revisited: A refined magnetostratigraphic calibration of dinoflagellate cyst events for the Oligocene of the Western Tethys. Rev. Palaeobot. Palynol. 158, 213-235.

Pross, J., Schmiedl, G., 2002. Early Oligocene dinoflagellate cysts from the Upper Rhine Graben (SW Germany): paleoenvironmental and paleoclimatic implications. Mar. Micropaleontol. 45, 1-24.

Pusz, A. E., Thunell, R. C., Miller, K. G., 2011. Deep water temperature, carbonate ion, and ice volume changes across the Eocene-Oligocene climate transition. Paleoceanography 26PA2205.

Quaijtaal, W., Brinkhuis, H., 2012. Pentadinium alabamensis: A new, unusual dinoflagellate from the early Oligocene of the Gulf Coast, Alabama, USA. Review of Palaeobotany and Palynology 175, 47-54.

Raymo, M.E., Mitrovica, J.X., O’Leary, M. J., DeConto, R. M., Hearty, P. J., 2011. Departures from eustasy in Pliocene sea level records. Nature Geoscience 4, 328-332.

Ribeiro, S., Lundholm, N., Amorim, A., Ellegaard, M., 2010. Protoperidinium minutum (Dinophyceae) from Portugal: cyst-theca relationship and phylogenetic position on the basis of single-cell SSU and LSU rDNA sequencing. Phycologia 49, 48-63.

Rochon, A., Lewis, J., Ellegaard, M., Harding, I. C., 2009. The Gonyaulax spinifera (Dinophyceae). Rev. Palaeobot. Palynol. 155, 52-60.

Röhl, U., Brinkhuis, H., Stickley, C. E., Fuller, C. E., Schellenberg, S. A., Wefer, G., Williams, G. L., 2004. Sea level and astronomically induced environmental changes in middle and late Eocene sediments from the East Tasman Plateau. In: Exon, N. F., Malone, M., Kennett, J. P. (Eds.), Climate evolution of the Southern Ocean and Australia's northward flight from Antarctica. American Geophysical Union Geophysical Research Series.

Sangiorgi, F., van Soelen, E. E., Spofforth, D. J., Palike, H., Stickley, C.E., St. John, K., Koc, N., Schouten, S., Sinninghe Damste, J. S., Brinkhuis, H., 2008. Cyclicity in the middle Eocene central Arctic Ocean sediment record: Orbital forcing and environmental response. Paleoceanography 23doi: 10.1029/2007PA001487, 2008.

Santarelli, A., Brinkhuis, H., Hilgen, F., Lourens, L., Versteegh, G., Visscher, H., 1998. Orbital signatures in a Late Miocene dinoflagellate record from Crete (Greece). Mar. Micropaleontol. 33, 273-297.

Scher, H. D., Bohaty, S. M., Zachos, J. C., Delaney, M. L., 2011. Two-stepping into the icehouse: East Antarctic weathering during progressive ice-sheet expansion at the Eocene-Oligocene transition. Geology 39, 383-386.

Schouten, S., Eldrett, J., Greenwood, D. R., Harding, I., Baas, M., Sinninghe Damsté, J. S., 2008. Onset of longterm cooling of Greenland near the Eocene-Oligocene boundary as revealed by branched tetraether lipids. Geology $36,147-150$. 
Schouten, S., Hopmans, E. C., Schefuss, E.Sinninghe Damsté, J.S., 2002. Distributional variations in marine crenarchaeotal membrane lipids: a new tool for reconstructing ancient sea water temperatures?. Earth \& Planetary Science Letters 204, 265-274.

Setiawan, J. R., 1983. Foraminifera and microfacies of the type Priabonian. Utrecht Micropaleontol. Bull. 29, 169.

Siesser, W. G., Fitzgerald, B. G., Kronman, D. J., 1985. Correlation of Gulf Coast provincial Paleogene stages with European standard stages. Bull. Geol. Soc. Am. 96, 827.

Sluijs, A., Brinkhuis, H., 2009. A dynamic climate and ecosystem state during the Paleocene-Eocene Thermal Maximum: inferences from dinoflagellate cyst assemblages on the New Jersey Shelf. Biogeosciences 6, 1755-1781.

Sluijs, A., Brinkhuis, H., Crouch, E. M., John, C. M., Handley, L., Munsterman, D., Bohaty, S. M., Zachos, J.C., Reichart, G. J., Schouten, S., 2008. Eustatic variations during the Paleocene-Eocene greenhouse world. Paleoceanography 23 .

Sluijs, A., Brinkhuis, H., Stickley, C. E., Warnaar, J., Williams, G. L., Fuller, M., 2003. Dinoflagellate cysts from the Eocene-Oligocene transition in the Southern Ocean: Results from ODP Leg 189. In: Exon, N. F., Kennett, J. P., Malone, M. J. (Eds.), Proceedings of the Ocean Drilling Program Volume 189.

Sluijs, A., Pross, J., Brinkhuis, H., 2005. From greenhouse to icehouse; organic-walled dinoflagellate cysts as paleoenvironmental indicators in the Paleogene. Earth Science Reviews 68, 281-315.

Sømme, T. O., Helland-Hansen, W., Granjeon, D., 2009. Impact of eustatic amplitude variations on shelf morphology, sediment dispersal, and sequence stratigraphic interpretation: Icehouse versus greenhouse systems. Geology 37, 587-590.

Stocchi, P. et al., 2013. Relative sea level rise around East Antarctica during Oligocene glaciation. Nature Geoscience 6, 380-384.

Tew, B. H., 1992. Sequence stratigraphy, lithofacies relationships, and paleogeography of Oligocene strata in southeastern Mississippi and southwestern Alabama. Geological Survey of Alabama, Stratigraphy and Paleontology Division.

Tew, B. H., Mancini, E. A., 1995. An integrated stratigraphic method for paleogeographic reconstruction: examples from the Jackson and Vicksburg groups of the Eastern Gulf Coastal Plain. Palaios 10, 133-153.
Torricelli, S., Knezaurek, G., Biffi, U., 2006. Sequence biostratigraphy and paleoenvironmental reconstruction in the early Eocene Figols Group of the Tremp-Graus Basin (south-central Pyrenees, Spain). Palaeogeogr. Palaeoclimatol., Palaeoecol. 232, 1-35.

Van Simaeys, S.de Man, E., Vandenberghe, N., Brinkhuis, H., Steurbaut, E., 2004. Stratigraphic and palaeoenvironmental analysis of the Rupelian-Chattian transition in the type region: evidence from dinoflagellate cysts, foraminifera and calcareous nannofossils. Palaeogeogr., Palaeoclimatol., Palaeoecol. 208, 31-58.

Wade, B.S., Houben, A. J. P., Quaijtaal, W., Schouten, S., Rosenthal, Y., Miller, K. G., Katz, M.E., Wright, J., Brinkhuis, H., 2012. Multiproxy record of abrupt seasurface cooling across the Eocene-Oligocene transition in the Gulf of Mexico. Geology 40, 159-162.

Wade, B.S., Pearson, P. N., 2008. Planktonic foraminiferal turnover, diversity fluctuations and geochemical signals across the Eocene/Oligocene boundary in Tanzania. Mar. Micropaleontol. 68, 244-255.

Wade, B. S., Pearson, P. N., Berggren, W. A., Pälike, H., 2011. Review and revision of Cenozoic tropical planktonic foraminiferal biostratigraphy and calibration to the geomagnetic polarity and astronomical time scale. Earth Science Reviews 104, 111-142.

Williams, G. L., Stover, L. E., Kidson, E. J., 1993. Morphology and stratigraphic ranges of selected Mesozoic-Cenozoic dinoflagellate taxa in the northern hemisphere. Geological Survey Canada paper 137.

Yamaguchi, T., Norris, R. D., Dockery, D. T., 2014. Shallowmarine ostracode turnover during the Eocene-Oligocene transition in Mississippi, the Gulf Coast Plain, USA. Marine Micropaleontology 106, 10-21.

Zachos, J.C., Quinn, T.M., Salamy, K. A., 1996. Highresolution $\left(10^{4}\right.$ years $)$ deep-sea foraminiferal stable isotope records of the Eocene-Oligocene climate transition. Paleoceanography 11, 251-266.

Zanazzi, A., Kohn, M. J., mac Fadden, B. J., Terry, O. D., 2007. Large temperature drop across the Eocene-Oligocene transition in central North America. Nature 445.

Manuscript received: November 11, 2017

Revisions required: February 23, 2018

Revised version received: June 15, 2018

Manuscript accepted: July 18, 2018 
154 A.J.P. Houben et al.

The pdf version of this paper includes an electronic supplement

Please save the electronic supplement contained in this pdf-file by clicking the blue frame above. After saving rename the file extension to .zip (for security reasons Adobe does not allow to embed .exe, .zip, . rar etc. files).

Table of contents - Electronic Supplementary Material (ESM)

A supplementary MS excel file accompanies this paper and contains a full list of taxa, quantitative distribution data, and $\mathrm{TEX}_{86}$ and BIT-data. 